\title{
Ocean colour remote sensing in the southern Laptev Sea: evaluation and applications
}

\author{
B. Heim ${ }^{1}$, E. Abramova ${ }^{5,6}$, R. Doerffer ${ }^{2}$, F. Günther ${ }^{1}$, J. Hölemann ${ }^{1,6}$, A. Kraberg ${ }^{1}$, H. Lantuit ${ }^{1}$, A. Loginova $^{3,4,6}$, \\ F. Martynov ${ }^{4,6}$, P. P. Overduin ${ }^{1}$, and C. Wegner $^{3}$ \\ ${ }^{1}$ Alfred-Wegener-Institut Helmholtz-Zentrum für Polar- und Meeresforschung, Germany \\ ${ }^{2}$ Helmholtz Centre Geesthacht HZG, Institute for Coastal Research, Geesthacht, Germany \\ ${ }^{3}$ GEOMAR Helmholtz Centre for Ocean Research, Kiel, Germany \\ ${ }^{4}$ St. Petersburg University, St. Petersburg, Russia \\ ${ }^{5}$ Lena Tiksi Reservate, Russia \\ ${ }^{6}$ Arctic and Antarctic Research Institute, Otto Schmidt Laboratory OSL, St. Petersburg, Russia
}

Correspondence to: B. Heim (birgit.heim@awi.de)

Received: 21 December 2012 - Published in Biogeosciences Discuss.: 28 February 2013

Revised: 25 January 2014 - Accepted: 30 January 2014 - Published: 12 August 2014

\begin{abstract}
Enhanced permafrost warming and increased Arctic river discharges have heightened concern about the input of terrigenous matter into Arctic coastal waters. We used optical operational satellite data from the ocean colour sensor MERIS (Medium-Resolution Imaging Spectrometer) aboard the ENVISAT satellite mission for synoptic monitoring of the pathways of terrigenous matter on the shallow Laptev Sea shelf. Despite the high cloud coverage in summer that is inherent to this Arctic region, time series from MERIS satellite data from 2006 on to 2011 could be acquired and were processed using the Case-2 Regional Processor (C2R) for optically complex surface waters installed in the open-source software ESA BEAM-VISAT.

Since optical remote sensing using ocean colour satellite data has seen little application in Siberian Arctic coastal and shelf waters, we assess the applicability of the calculated MERIS C2R parameters with surface water sampling data from the Russian-German ship expeditions LENA2008, LENA2010 and TRANSDRIFT-XVII taking place in August 2008 and August and September 2010 in the southern Laptev Sea. The shallow Siberian shelf waters are optically not comparable to the deeper, more transparent waters of the Arctic Ocean. The inner-shelf waters are characterized by low transparencies, due to turbid river water input, terrestrial input by coastal erosion, resuspension events and, therefore, high background concentrations of suspended particulate matter and coloured dissolved organic matter.
\end{abstract}

We compared the field-based measurements with the satellite data that are closest in time. The match-up analyses related to LENA2008 and LENA2010 expedition data show the technical limits of matching in optically highly heterogeneous and dynamic shallow inner-shelf waters. The matchup analyses using the data from the marine TRANSDRIFT expedition were constrained by several days' difference between a match-up pair of satellite-derived and in situ parameters but are also based on the more stable hydrodynamic conditions of the deeper inner- and the outer-shelf waters. The relationship of satellite-derived turbidity-related parameters versus in situ suspended matter from TRANSDRIFT data shows that the backscattering coefficient C2R_bb_spm can be used to derive a Laptev-Sea-adapted SPM algorithm. Satellite-derived Chl $a$ estimates are highly overestimated by a minimum factor of 10 if applied to the inner-shelf region due to elevated concentrations of terrestrial organic matter.

To evaluate the applicability of ocean colour remote sensing, we include the visual analysis of lateral hydrographical features. The mapped turbidity-related MERIS C2R parameters show that the Laptev Sea is dominated by resuspension above submarine shallow banks and by frontal instabilities such as frontal meanders with amplitudes up to $30 \mathrm{~km}$ and eddies and filaments with horizontal scales up to $100 \mathrm{~km}$ that prevail throughout the sea-ice-free season. The widespread turbidity above submarine shallow banks indicates innershelf vertical mixing that seems frequently to reach down to 
submarine depths of a minimum of $10 \mathrm{~m}$. The resuspension events and the frontal meanders, filaments and eddies indicate enhanced vertical mixing being widespread on the inner shelf.

It is a new finding for the Laptev Sea that numerous frontal instabilities are made visible, and how highly time-dependent and turbulent the Laptev Sea shelf is. The meanders, filaments and eddies revealed by the ocean colour parameters indicate the lateral transportation pathways of terrestrial and living biological material in surface waters.

\section{Introduction}

The objective of this paper is to depict the bio- and geooptical characteristics of the southern Laptev Sea coastal and inner-shelf waters and to discuss the applicability of ocean colour remote sensing for the shallow Laptev Sea shelf region. Together with the eastern Siberian shelf the Laptev Sea region is part of the world's broadest shelf system. Freshwater river input (Gordeev et al., 1996; Rachold et al., 2000; Lobbes et al., 2000; Fedorova et al., this volume) and terrestrial fluxes from the coastal zone (e.g. Schirrmeister et al., 2002; Charkin et al., 2011; Vonk et al, 2010; Lantuit et al., 2011, 2012; Vonk et al., 2012; Rachold et al., 2004; Günther et al., 2013a, this volume, b) deliver large volumes of terrestrial matter in particulate and dissolved form into the Laptev Sea shelf system. Semiletov et al. (this volume) present a summary on their multi-year investigations in the Laptev Sea and Eastern Siberian Sea shelf system, discussing the source of elevated coloured Dissolved Organic Matter (cDOM) that they find all over on the Laptev Sea shelf being mainly related to the runoff of the large Siberian river systems, and coastal erosion providing the elevated concentrations of Particulate Organic Matter Carbon (POC) and nutrients. Karlsson et al. (2011), Sánchez-García et al. (2011), and Vonk et al. (2012) showed that old POC in the Laptev Sea shelf waters originates from Ice Complex desposits, the younger to modern POC originating from fluvial discharge.

We know that the main far-reaching transport processes of terrestrial particles are regulated (i) with the sea ice transport with sediments scraped up from the numerous submarine shallows, from the coastal zone and suspended particulate matter from the water column incorporated into sea ice (Aagaard and Armack, 1989; Eicken et al., 1997, 2000; Wegner et al., 2005), and (ii) within the bottom nepheloid layer, a layer of increased suspended matter concentration in submarine valley structures that serve as transport pipes (Wegner et al., 2003, 2005). The input of terrestrial matter into the shallow Laptev Sea shelf system seems to be far-reaching: Vonk et al. (2012), Gustavson et al. (2011), and Lobbes et al. (2000) showed that terrestrial markers such as lignin and others are present over the whole Siberian shelf and assumed that the river spring freshets and the sea ice are the main transport pathways.

Can ocean colour remote sensing reveal new information on the Laptev Sea hydrography and its spatio-temporal dynamics? Ocean colour remote sensing uses spectroradiometrically high-performance optical sensors (www.ioccg. org/) with high-temporal-resolution and long-term time series, such as the Coastal Zone Colour Scanner, CZCS; Sea-viewing Wide Field-of-view Sensor, SeaWiFS; Moderate Resolution Imaging Spectroradiometer, MODIS; and the Medium Resolution Imaging Spectrometer, MERIS satellite missions. The two MODIS space missions on the satellite platforms TERRA and AQUA are currently the most important operating polar-orbiting ocean colour missions (http://modis.gsfc.nasa.gov/). Operational ocean colour remote sensing products are quantitative optical parameters such as attenuation and absorption coefficients, and concentrations of chlorophyll ( $\mathrm{Chl} a$ ), Suspended Particulate Matter (SPM), and cDOM.

Ocean colour remote sensing has the potential to provide large-scale estimates of these optical parameters in this remote region. The use of ocean colour remote sensing in polar regions is, however, impeded by a number of difficulties and limitations that was summarized by the International Ocean Colour Coordinating Group (IOCCG, www. ioccg.org/): among other challenging factors, the waters over the Arctic shelves are optically complex because of the important freshwater inputs. Previous studies in the Beaufort Sea (Canadian Arctic) indicated that National Aeronautics and Space Administration (NASA) standard algorithms for SeaWiFS and MODIS overestimated the Chl $a$ concentration as a result of different optical properties of the phytoplankton and the presence of cDOM (Cota et al., 2004; Matsuoka et al., 2007, 2012a, b, 2013; Mustapha et al. 2012). Few optical studies of Arctic waters exist up to date. Currently, the Malina project investigated how biodiversity and biogeochemical fluxes in the Arctic Ocean are controlled by light penetration and gave new insights into the biogeochemical optical peculiarities of the Beaufort Sea (Bélanger et al., 2008, 2013; Matsuoka et al., 2012a, b, 2013; Doxaran et al., 2012; Antoine et al., 2013). Antoine et al. (2013) show in their observational overview and assessment of bio-optical water column relationships that a larger contribution of absorption by cDOM is responsible for high attenuation coefficients as compared to other oligotrophic areas. The authors discuss that specifically in turbid waters, where attenuation reaches high values, driven by high loads of particulate materials and also by high cDOM, the current satellite Chl $a$ algorithms fail. The 3rd report (2000) of the IOCCG described the phenomenon of optically complex surface waters (coastal waters, fluvial and limnic systems) designating such surface waters as Case- 2 waters in contrast to Case1 waters dominated optically by phytoplankton. The ocean colour processing linked to Case- 2 waters requires specific atmospheric correction schemes due to non-zero upwelling 
radiances in the near-infrared (NIR) wavelength region and specific bio-optical algorithms to account for $\mathrm{CDOM}$ and particulates in particular. Since 2010, the CoastColour project of the European Space Agency (ESA) has incorporated the Kara Sea and Laptev Sea regions into its program for evaluating the applicability of ocean colour remote sensing in Arctic coastal waters. In support of this programme, the optical remote sensing parameters were calculated within this study from the ocean colour sensor MERIS using a CoastColour processing method: the Case-2 Regional Processor module (C2R; Doerffer and Schiller, 2007, 2008) installed in BEAM-VISAT (Brockmann Consult) was used to process the MERIS top-of-atmosphere (TOA) radiances to obtain optical variables and concentrations of Chl $a$, SPM, and cDOM.

The first step in the present study is to depict the biogeochemical characteristics from the shallow Laptev Sea shelf waters with collected in situ data from the RussianGerman ship expeditions LENA08 (L08), LENA10 (L10) and TRANSDRIFT-XVII in 2008 and 2010. The expeditions were not specifically designed for the validation of optical remote sensing; they investigated the hydrographical dynamics and bio- and geochemistry in the Laptev Sea. Their worth lies in providing field-based optical parameters such as transmissivity, SPM, cDOM, and Chl $a$. Exact match-up analyses take the remote sensing value from the pixel location on the same day of the ship-based in situ measurement. However, optical remote sensing applications in polar regions are severely limited by the prevailing low solar elevations and the persistence of clouds and fog (IOCCG, 2000). Also for the Laptev Sea region, south of the sea ice boundary, continuous cloud coverage prevails north of $75^{\circ} \mathrm{N}$ at a longitude of $130^{\circ} \mathrm{E}$ and westwards of it during the sea-ice-free summer months. Also south of $75^{\circ} \mathrm{N}$ the temporal resolution of usable optical satellite data may be as low as one successful area-wide acquisition per month in some years. Therefore, we rarely had the temporal coincidence of one day but used the satellite data that are closest in time for comparing the value ranges of optical parameters from field-based sampling. We investigate whether the value ranges of the derived MERIS C2R satellite products seem to be valid for the specific water types.

As a second step, we include the visual analysis of lateral hydrographical features. Lateral hydrographical features of this shallow Siberian shelf system cannot be made visible from sampling from shipborne platforms alone, because high-sea Arctic ship expeditions are forced to stay in deeper waters due to their draft. Even with grid sampling from shallow-water-going ships it would be difficult to capture these spatial features as sampling cannot logistically be done with a good-enough spatial resolution. Since ship-based sampling is logistically constrained in spatial and temporal coverage, optical satellite data provide additional data in space and time. Since the turbidity-related parameters display frontal features with value changes of one magnitude, a visual interpretation of the spatio-temporal pattern of the mapped ocean colour parameters is feasible. Like this, we hope to gain insights from optically visible events towards information on surface water processes.

\section{Hydrography of the Laptev Sea}

The Laptev Sea is an open marginal sea of the Arctic Ocean bounded by the Taymyr Peninsula on the west and the New Siberian Islands on the east. The sedimented shelf material and the sedimentary-ice-rich parts of the central and eastern Siberian coastline (Lantuit et al., 2011; Schirrmeister et al., 2002) steam from the extreme climatic conditions during the late Pleistocene during which the large unglaciated shelves were exposed. This triggered the accumulation of the northern Siberian Ice Complex and of fluvial sediments on the exposed shelves. Gavrilov et al. (2003) discuss that the numerous present-day submarine shallows represent former Ice Complex islands that have been destroyed during the last thousand years. Several submarine banks are delineated by the $-5 \mathrm{~m},-10 \mathrm{~m}$ and $-15 \mathrm{~m}$ isobaths (State Geological Map of Russian Federation, 1999) on the Laptev Sea shelf and in the western part of the Eastern Siberian Sea shelf (Fig. 1a).

Around the Lena River delta, Reimnitz (2000) describes a wide shallow submarine bank that is characteristic of Arctic deltas most probably generated by bottom-fast ice cover. The Lena River delta is the largest delta in the Arctic and undergoes considerable block uplift that controls the delta's topography and drainage system (Fig. 1b); the Lena River is the second-largest Arctic river and discharges $581 \mathrm{~km}^{3}$ freshwater annually (Holmes et al., 2012), delivering an average annual sediment input of $20.7 \mathrm{Mt}$ (Rachold et al., 2004). The main modern Lena River branches enter the southern Laptev Sea (Buor-Khaya Gulf) through the northern and eastern part of the Lena River delta: the Trofimovsko-Sardakhskaya channel systems with 60-75\%, and the Bykovskaya channel with $20-25 \%$. The Olenyeksky and Tumatskaya branches with $5-10 \%$ of water discharge flow westwards, (Fedorova et al., this volume). Fedorova et al. (this volume) distinguished three periods with various water volumes and intensity of fluvial processes from 1977 on. Most of the freshwater river input is discharged during the end of May and beginning of June, when the ice in the rivers breaks up, while the Laptev Sea is still covered by sea ice (Holmes et al., 2012). In the sea, the prevailing atmospheric systems of the cyclonic or anti-cyclonic Arctic circulation are the main driving forces of the coastal and marine Laptev Sea currents (Wegner et al., this volume; Bauch et al., 2009; Dmitrenko et al., 2005).

\section{Material and methods}

\subsection{Surface water sampling and analyses}

The coastal L08 expedition sampled along the Bykovskaya Lena River mouth and the western Buor-Khaya Gulf from 9 to 14 August 2008 (Fig. 1a, b) (Wagner et al., 2012). 


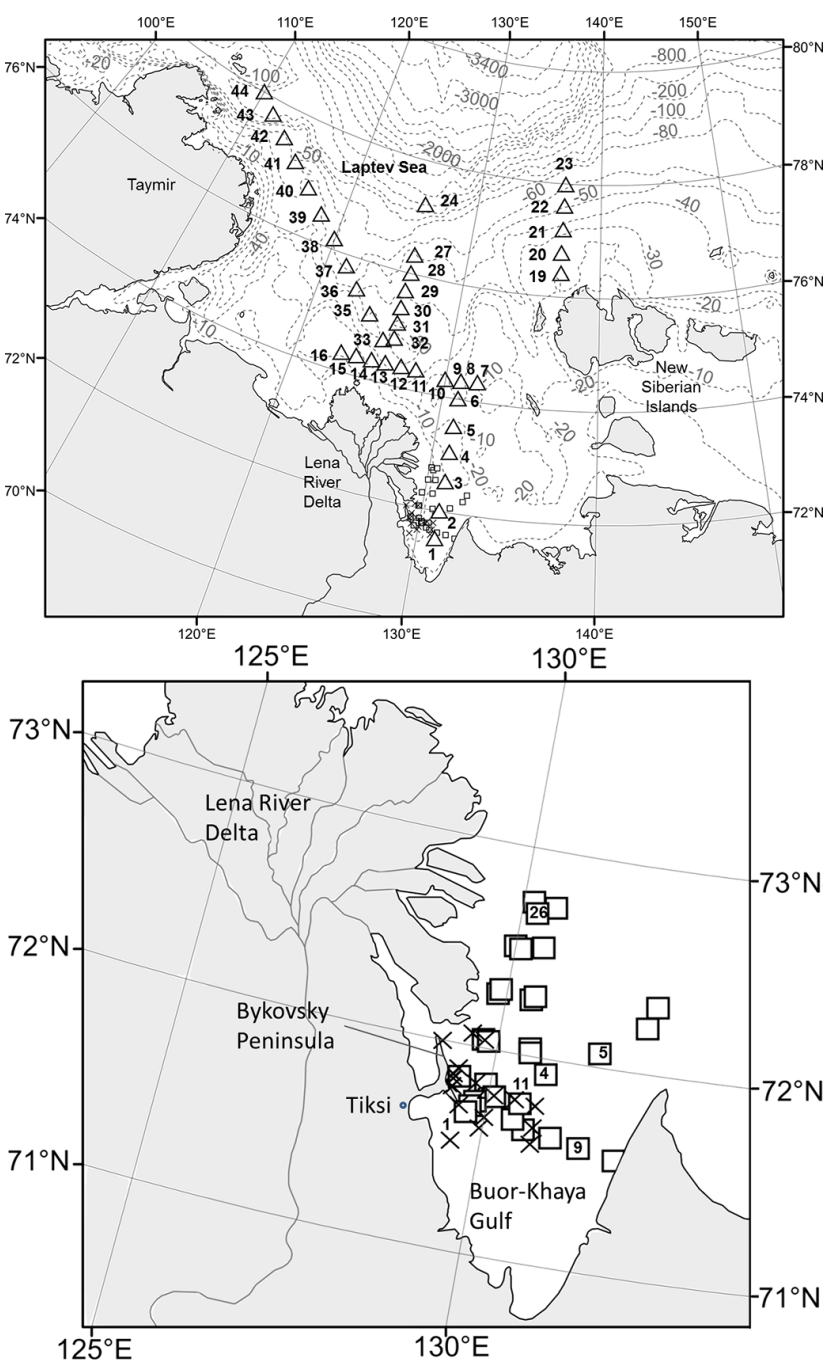

Figure 1. (a) The Southern Laptev Sea, Arctic Siberia (Russian Federation). Stations of the LENA2008 and the LENA2010 ship expeditions (August 2008 and August 2010) in the Buor-Khaya Gulf are displayed as small symbols of crosses and squares. Stations of the TRANSDRIFT-XVII ship expedition (from 9 to 20 September 2010) from the inner- to the outer-shelf waters are displayed as triangles. (b) The overview on the Lena River delta and the BuorKhaya Gulf area shows the Lena River branches and the Bykovsky Peninsula sheltering the Tiksi Bay. Stations of the LENA2008 ship expedition southeast of the Lena River delta (from 9 to 14 August 2008) are displayed as crosses. Stations of the LENA2010 ship expedition in the Buor-Khaya Gulf (from 29 July to 7 August 2010) are displayed as squares.

From 29 July to 8 August 2010, the L10 ship expedition sampled along several transects throughout the Buor-Khaya Gulf (Fig. 1a, b). The marine ship expedition TRANSDRIFTXVII took place on the inner shelf and outer shelf from 9 to 20 September 2010 (Fig. 1a). Table 1 provides an overview on data taken and match-ups used of the three expeditions. Hydrographical investigations were carried out with conductivity-temperature-depth meter (CTD) sensor casts on L10 and on TRANSDRIFT. On L10, CTD vertical profiles were taken with a Sea and Sun Technology $\mathrm{GmbH}$ device, on TRANSDRIFT with a CTD of type SeaBird Electronics SBE19+ connected to a carousel water sampler SBE32C equipped with additional sensors for measuring water turbidity (Seapoint OBS), dissolved oxygen concentration (SBE43) and Chl $a$ fluorescence (WETlabs WETstar, USA). A second CTD cast was operated with a CDOM sensor (WETstar, USA) but could technically not be operated at all stations.

SPM [L08, TRANSDRIFT]: in 2008 on L08, $1 \mathrm{~L}$ was filtered through $0.45 \mu \mathrm{m}$ pore size preweighed cellulose-acetate with the elutable portion of the used filters $<0.2 \mathrm{mg} \mathrm{L}^{-1}$. In 2010 on TRANSDRIFT, $0.5 \mathrm{~L}$ was filtered for SPM through $0.45 \mu \mathrm{m}$ pore size MILLIPORE Durapore membrane filters, with the elutable portion of the used filters $<0.3 \mathrm{mg} \mathrm{L}^{-1}$. On both expeditions, SPM filters were ovendried and preweighed and were redried prior to weighting under a dry atmosphere.

cDOM [L08, L10, TRANSDRIFT]: cDOM is operationally defined by the chosen filter pore size. Investigations of other authors (e.g. Laanen et al., 2011) comparing laboratory cuvette absorption measurements with absorption measurements in a calibrated point-source integrating-cavity absorption meter (PSICAM) found that filtration over $0.7 \mu \mathrm{m}$ pore size caused a systematic $8 \%$ overestimation of cDOM measured in the cuvette caused by the residual scattering. By filtering over $0.2 \mu \mathrm{m}$ cDOM cuvette values were $6 \%$ underestimated because also a significant fraction of absorption was removed from the sample. Marine DOC measurement protocols are based on $0.7 \mu \mathrm{m}$ pore size glass-fibre (GF) filtrates. We consistently filtered through $0.7 \mu \mathrm{m}$ pore size $\mathrm{GF} / \mathrm{F}$ filters for $\mathrm{CDOM}$ and DOC for matching comparable filtrates. Care was taken that the first $200 \mathrm{ml}$ of the filtrate with the elutable portion from filters was discarded. $\mathrm{cDOM}$ filtrates were stored in brown quartz glass bottles, put in the dark and measured following each expedition using a dual-beam Specord200 (Jena Analytik). Optical density (OD) spectra of the filtrates were measured from 300 to $750 \mathrm{~nm}$ using acidcleaned quartz cuvettes mode according to the absorption intensity of the samples. OD of each sample was measured three times against ultra-pure water that was changed every sample to not overheat the reference sample that needs to be at the same temperature as the room-warmed sample. Absorption per metre was calculated based on the averaged OD value of each sample using $2.303 \times \mathrm{OD} / 0.1$ for the $10 \mathrm{~cm}$ cuvette, and $2.303 \times \mathrm{OD} / 0.05$ for the $5 \mathrm{~cm}$ cuvette.

Because the spectrophotometrically measured cDOM absorption values cover more sampling stations, the data analyses presented in this paper used the spectrophotometrical cDOM data.

Chl $a$ [TRANSDRIFT]: on TRANSDRIFT $1 \mathrm{~L}$ water was filtered for Chl $a$ through $0.7 \mu \mathrm{m}$ pore size Whatman GF filters with a pressure of not more than $0.2 \mathrm{bar}$. The $\mathrm{Chl} a$ filters 
Table 1. LENA08, LENA10, TRANSDRIFT-XVII: in situ parameters and stations used in this study.

\begin{tabular}{|c|c|c|c|c|}
\hline Expedition & Code & Eates & $\begin{array}{l}\text { In situ parameters } \\
\text { used for this study }\end{array}$ & $\begin{array}{l}\text { Stations used for match-ups } \\
\text { (date): stations }\end{array}$ \\
\hline LENA08 & L08 & $\begin{array}{l}8-14 \\
\text { August } \\
2008\end{array}$ & $\begin{array}{l}\text { cDOM, SPM } \\
\text { Secchi-depth }\end{array}$ & - \\
\hline LENA10 & L10 & $\begin{array}{l}29 \text { July- } \\
7 \text { August } \\
2010\end{array}$ & $\begin{array}{l}\text { cDOM, } \\
\text { CTD (Sea and Sun } \\
\text { Technology), } \\
\text { (transmissivity*) } \\
\text { *technical problems }\end{array}$ & $\begin{array}{l}\text { (4 Aug 2010): } 1,2,4,5 \\
\text { (5 Aug 2010): } 9,11 \\
\text { (6 Aug 2010): } 26\end{array}$ \\
\hline $\begin{array}{l}\text { TANSDRIFT- } \\
\text { XVII }\end{array}$ & $\begin{array}{l}\text { TRANS } \\
\text { DRIFT }\end{array}$ & $\begin{array}{l}9-20 \\
\text { September } \\
2010\end{array}$ & $\begin{array}{l}\text { cDOM, SPM, Chl } a \\
\text { CTD (SeaBird SBE19+) }\end{array}$ & $\begin{array}{l}\text { (9 Sep 2010): NE10-01, 2, 3, 4, } 5 \\
\text { (10 Sep 2010): NE10-06 } \\
\text { (12 Sep 2010): NE10-08, 9, 10, } 13 \\
\text { (13 Sep 2010): NE10-14, 15, 16, 17, } 19 \\
\text { (16 Sep 2010): NE10-20, 21, 22, } 23 \\
\text { (17 Sep 2010): NE10-27, 28 } \\
\text { (18 Sep 2010): NE10-29, 30, } 34 \\
\text { (19 Sep 2010): NE10-35 }\end{array}$ \\
\hline
\end{tabular}

were immediately frozen on site. Chl $a$ from filters was measured after extraction with the non-acidification technique using a TD-700 fluorimeter according to the US Environmental Protection Agency Method 445.0 (Rev. 1.2) for determination of $\mathrm{Chl} a$ by fluorescence. According to previous TRANSDRIFT expeditions the WETlabs in situ Chl $a$ fluorescence values showed an overestimation of a factor of 3.5 compared to in situ $\mathrm{Chl} a$ from filters and was accordingly corrected by this factor. The Chl $a$ fluorescence profiles were only used to investigate the mixing or stratification regime from the shape of the vertical profile. The Chl $a$ match-up analyses carried out within this study are based on the fluorimetrically measured $\mathrm{Chl} a$ from the Chl $a$ filters.

\subsection{Satellite data processing and analyses}

MERIS was operated on the European Space Agency's ENVISAT satellite platform from 2002 to 2012 as a wide fieldof-view $\left(68.5^{\circ}\right)$ push broom imaging spectrometer with a swath width of $1150 \mathrm{~km}$. MERIS measured the solar radiation reflected by the Earth's surface in the visible and NIR wavelength ranges in 15 spectral bands from 390 to $1040 \mathrm{~nm}$. MERIS Reduced Resolution (RR) data are approximately $1 \mathrm{~km}$ at nadir $(1040 \mathrm{~m} \times 1200 \mathrm{~m}$ pixel $)$ and are available with a global daily coverage until 2012. The MERIS RR Level1B TOA radiances can be acquired from the ESA archive. For the time window of the sea-ice-free season from 2006 to 2011 in the months of July, August and September we found between 5 and 15 MERIS acquisitions per year that show relatively large cloud-free areas of the Laptev Sea region.

MERIS RR Level-1B data were processed using BEAMVISAT4.10 ${ }^{\odot}$ with the MERIS C2R processor for coastal application (Doerffer and Schiller, 2007, 2008). The C2R processing modules use neural networks to inversely model water-leaving reflectances of MERIS spectral bands 1-8 from calculated TOA reflectances after ozone, water vapour and surface pressure correction. Inverse modelling using neural networks is then used to derive $\mathrm{C} 2 \mathrm{R}$ aquatic parameters from the water-leaving reflectances. The bio-optical forward model is parameterized with spectroradiometric coefficients specific to coastal Case-2 waters (Doerffer and Schiller, 2007, 2008). The C2R processing modules are continuously updated and optimized.

C2R output parameters are estimated atmospheric and aquatic parameters, such as the water-leaving reflectances, the attenuation, absorption and backscattering coefficients, and calculated concentrations of Chl $a$ (C2R_Chl $a$ ), SPM (C2R_TSM (total suspended matter)), and cDOM (C2R_a_ys (yellow substance absorption)). The C2R_Chl $a$ standard product is determined from an empirically derived global relationship between absorption (a_pig) and Chl $a$ concentration with a conversion factor of 21 . In this study, we applied a regionally specific relationship for phytoplankton adapted to dark waters (due to cDOM absorption) derived from Örek et al. (this volume) with a conversion factor of 7.8. That is a lower conversion factor than normally found for open and coastal water phytoplankton.

We also calculated the parameter Chl $a$ from operational empirical algorithms such as the global Chl $a$ algorithm for MERIS, the OC4Mev6 and the Arctic Chl $a$ algorithms of the SeaWiFS algorithm (OC4L and OC4P) from the waterleaving C2R reflectances $R_{\mathrm{rs}}\left(\mathrm{sr}^{-1}\right)$ (Appendix A). The Arctic Chl $a$ algorithms Arctic OC4L (Wang and Cota, 2003) and OC4P (Cota et al., 2004) are a polynomial and a linear 
version based on in situ measurements in Canadian Arctic waters (Appendix A).

We investigated the relationship between the backscattering coefficient, C2R_bb_spm, the band ratio $R_{\mathrm{rs}} 778 / R_{\mathrm{rs}} 560$ and the TRANSDRIFT in situ SPM values. We also applied the Beaufort-Sea/Mackenzie-specific SPM algorithm developed by Doxaran et al. (2013) (Appendix A) based on a multitude of in situ measurements along the Mackenzie River plume, Beaufort Sea.

All the calculated remote sensing optical parameters and concentrations are representative of the first attenuation depth that is equivalent to the water depth layer wherefrom $90 \%$ of the water-leaving signal originates, $Z_{90}$. It is the depth at which the surface light field reduces to $e^{-1}$ or $\sim 37 \%$ of its initial value according to Beer's law. The C2R parameter of the first attenuation depth, C2R_Z90, is calculated according to the two-flow model from Gordon and McCluney (1975). C2R_k $k_{\min }$, the diffuse coefficient of the minimum attenuation, is calculated within the photosynthetically active radiation (PAR) wavelength region. The euphotic depth, $Z_{\mathrm{Eu}}$, down to which significant phytoplankton photosynthesis can occur, is set to the depth where the incident surface light falls to $1 \%$. (Appendix A).

For the Laptev Sea region, a problem is undetected thin clouds and fog that cannot be detected within the automatic processing. These artefacts are visible in the atmospherically processed Level-2 products as sharply outlined features with under- and overestimated parameters. The choice of raising the cloud-detection threshold level for the TOA radiances would essentially exclude large areas of coastal and innershelf turbid waters. Therefore, the sharply outlined features were manually extracted and excluded from the match-up analyses.

\subsection{Match-up analyses with MERIS C2R parameters}

The MERIS acquisitions on 31 July, 3-6 August and $10 \mathrm{Au}-$ gust 2010 show low cloud coverage and are close in time to the L10 ship expedition in the Buor-Khaya Gulf that took place from 29 July to 7 August 2010. A MERIS acquisition on 7 September 2010 is the cloud-free acquisition closest in time to the TRANSDRIFT expedition that took place from 9 to 20 September 2010. The next usable MERIS acquisitions on 18 and 20 September 2010 have higher cloud coverage.

Exact match-up analyses take the remote sensing value from the pixel location on the same day of the ship-based in situ measurement. For the Laptev Sea region this is not feasible due to frequent cloud coverage. Match-up analyses using spatial averages of pixels could be a technical solution. However, for the Laptev Sea, the high spatial and high temporal horizontal heterogeneity confounds the spatially averaged match-up analyses. Figure $2 \mathrm{a}-\mathrm{c}$ show the difficulty of match-up analyses and high variability for the coastal waters. For example, the L10 sampling stations 1 to 3 and 25 are of the turbid water type with values C2R_Z90 of $\sim 1 \mathrm{~m}$ on 3 August 2010, changing to more transparency with values C2R_Z90 of $\sim 2 \mathrm{~m}$ only within 1 to 2 days due to frontal changes. Therefore, match-up pairs in coastal waters were chosen from the same day of the MERIS acquisition.

The TRANSDRIFT expedition covered water types from outer-shelf to inner-shelf waters. The temporal differences for match-ups on TRANSDRIFT accounted for 2 to 11 days. The best matching coordinate pairs in time were selected for the match-up analyses. The temporal delay of up to 11 days occurred only for the TRANSDRIFT transects in the nonturbid outer-shelf waters. The outer-shelf is out of the reach of the dynamical frontal changes of the turbidity-influenced shallow water zones (Fig. 3).

The in situ expedition data taken for the match-up analyses were averaged over the first $2 \mathrm{~m}$ water layer from discrete samples for cDOM, SPM and Chl $a$. L10 and TRANSDRIFT CTD data show a homogenous, mixed layer in every case within this depth.

\section{Results}

\subsection{Ranges of optically visible water parameters in the southern Laptev Sea}

\subsubsection{Hydrography}

The shallow waters above the submarine banks around the eastern Lena River delta were well mixed down to the sea bottom at to a depth of 5 to $8 \mathrm{~m}$. Stratification due to the riverine freshwater occurred in the Buor-Khaya Gulf with a sharp halocline below 5 to $8 \mathrm{~m}$ in August 2010 (L10), and below 12 $\mathrm{m}$ with surface temperature around $8^{\circ} \mathrm{C}$ in September 2010 (TRANSDRIFT). The east-west transect north of the Lena River delta (samples 8-16) shows transitional hydrological values with temperatures around $3{ }^{\circ} \mathrm{C}$, and an averaged salinity of 22.6 at most stations. The outer-shelf waters showed a salinity of 32 .

\subsubsection{Transparency and SPM}

Lena River and near-shore waters in 2008 and 2010 had in situ Secchi-depths of less than $0.5 \mathrm{~m}$ with value ranges of 5 to $20 \mathrm{mg} \mathrm{L}^{-1} \mathrm{SPM}$ (within the upper $2 \mathrm{~m}$ water layer). The shallow water types (up to $\sim 8 \mathrm{~m}$ water depth) around the Lena River delta and in the Buor-Khaya Gulf were characterized by a wide range of SPM concentrations from 3 to $18 \mathrm{mg} \mathrm{L}^{-1}$, in situ Secchi-depths of 1 to $1.5 \mathrm{~m}$ in 2008 and measured transmissivity ranging from 60 to $75 \%$ in 2010 . Figure $4 a$ displays the TRANSDRIFT SPM concentrations at the stations. SPM ranges in 2010 in the deeper central Buor-Khaya Gulf (samples 1,3,5,6, > $8 \mathrm{~m}$ water depth) showed concentrations of 1.5 to $3 \mathrm{mg} \mathrm{L}^{-1}$. Equivalent to this SPM concentration range, deeper Buor-Khaya Gulf waters ( $>8 \mathrm{~m}$ water depth) had in situ Secchi-depths of up to $2 \mathrm{~m}$ in 2008. On TRANSDRIFT, also peaks of SPM concentrations of 5 to 

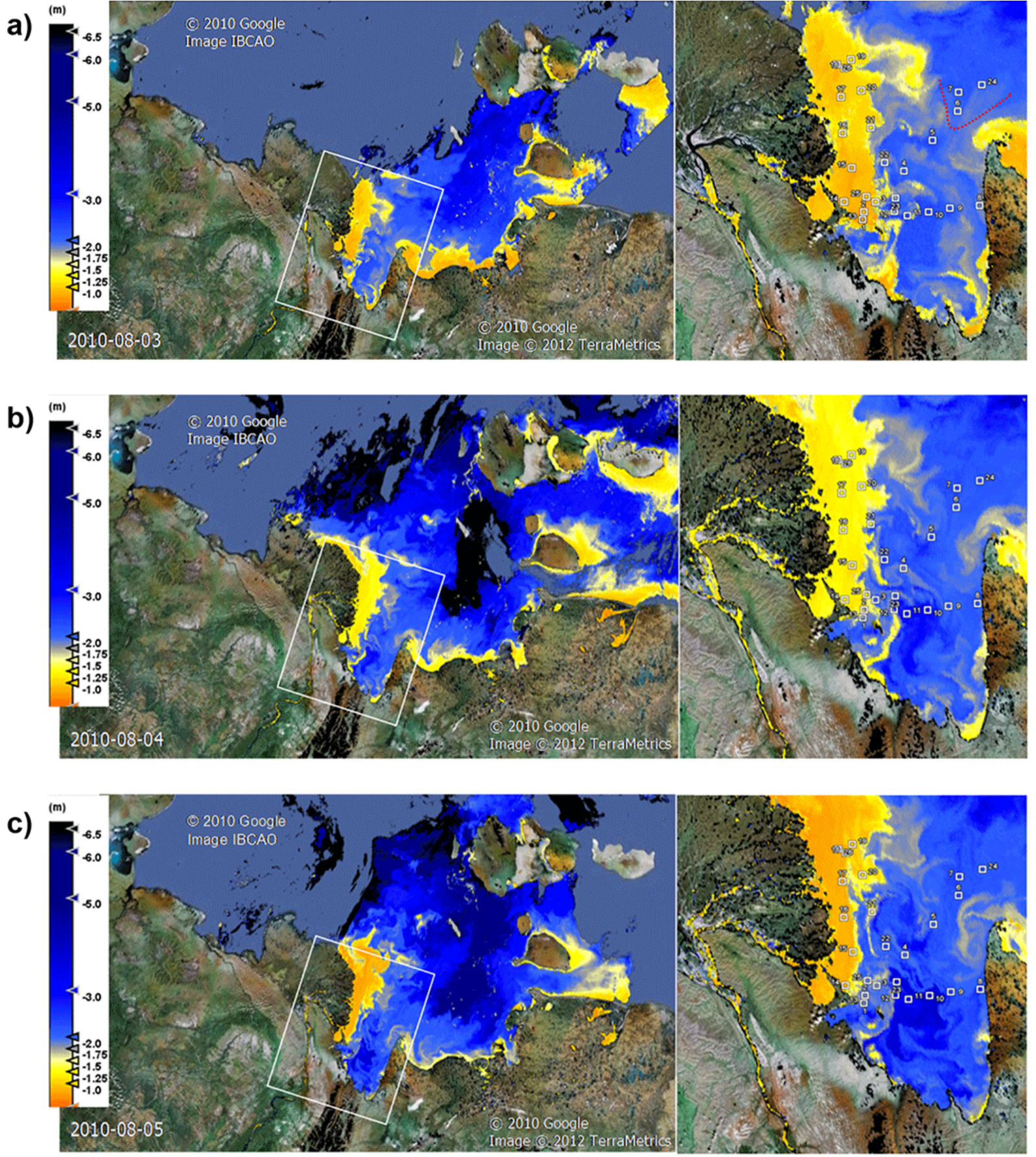

Figure 2. MERIS colour-coded maps of C2R_Z90, the first attenuation depth, of the Buor-Khaya Gulf with the land and detected clouds transparently masked. The transparent masks display the Google Earth ${ }^{\text {TM }}$ land mosaic and the IBCAO bathymetry $\left({ }^{\odot} 2010\right.$ Google, Image ${ }^{0} 2012$ TerraMetrics, Image IBCAO) as background. (a) 3 August 2010; the salinity isoline = 8 is schematically displayed as red outline close to the most northeastern L10 stations (6, 7, 24). Southwards, freshwater dominates (salinity < 5), and (b) 4 August 2010 and (c) 5 August 2010 are the cloud-free MERIS acquisitions within the time window of the L10 expedition (from 29 July to 7 August 2010 ).

$6 \mathrm{mg} \mathrm{L}^{-1}$ occurred in the Buor-Khaya Gulf (samples 4, 12, 15). TRANSDRIFT SPM ranges in 2010 showed SPM concentrations between 0.5 and $1 \mathrm{mg} \mathrm{L}^{-1}$ on the outer shelf together with marine salinities of 32 . Table 2 gives an overview on measured salinities and SPM. In summary, the low salinities occurred together with a wide value range of SPM concentrations covering the Lena River waters, coastal waters and inner-shelf waters. 


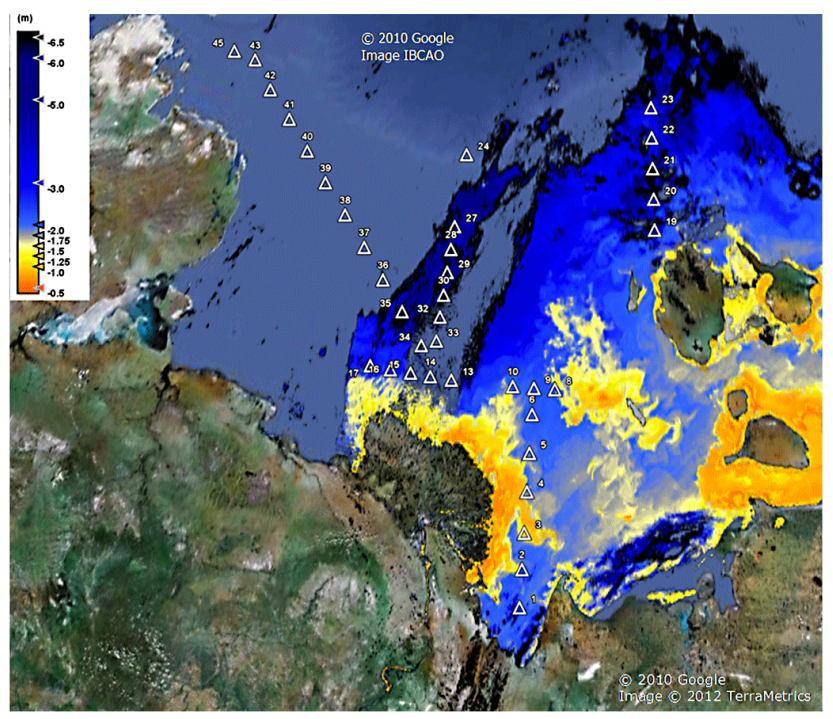

Figure 3. MERIS colour-coded map of C2R_Z90, the first attenuation depth, 7 September 2010 at 10:48 a.m. (local time) with the land and detected clouds transparently masked. The transparent masks display the Google Earth $^{\mathrm{TM}}$ land mosaic and the IBCAO bathymetry $\left({ }^{\circledR} 2010\right.$ Google, Image ${ }^{{ }^{\circledR}} 2012$ TerraMetrics, Image IBCAO) as background. Stations of the TRANSDRIFT-XVII ship expedition in September 2010 are displayed as triangles.

\subsection{3 cDOM}

Measured cDOM values in Lena River waters and in the surface waters of the Buor-Khaya Gulf were of high magnitudes during the summers 2008 and 2010. Coastal waters close to melt water outflows of the permafrost coast showed

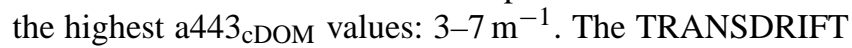
samples in September 2010 also show the elevated surface water cDOM concentrations in inner-shelf waters. Ranges for the absorption of cDOM at $443 \mathrm{~nm}, \mathrm{a} 443_{\mathrm{cDOM}}$, were as follows: Lena River, a443 $3_{\mathrm{cDOM}}: 1.3-3.5 \mathrm{~m}^{-1}$; mixed onshore waters, a $443_{\mathrm{CDOM}}: 2.5-4 \mathrm{~m}^{-1}$; stratified offshore waters ( $>8 \mathrm{~m}$ water depth) in the Buor-Khaya Gulf, a $443_{\mathrm{cDOM}}$ : $1.5-3 \mathrm{~m}^{-1}$; on the inner shelf: $1-1.5 \mathrm{~m}^{-1}$; and on the outer shelf: $0.4-0.6 \mathrm{~m}^{-1}$ (Table 2). Figure $4 \mathrm{~b}$ displays the TRANSDRIFT cDOM concentrations at the stations. More than 100 $\mathrm{km}$ north of the Lena River delta along the east-west transect, high cDOM concentrations of $1.2 \mathrm{~m}^{-1}$ were still encountered (samples 8-16). A cDOM maximum of $1.7 \mathrm{~m}^{-1}$ occurred north of the New Siberian Islands (sample 19).

The cDOM values showed a nearly conservative mixing within a wide salinity range (0-32) (Loginova et al., 2011). The relationship of cDOM versus salinity on the L10 and TRANSDRIFT ship expeditions in 2010 (Fig. 5) shows the quasi-conservative mixing behaviour of spectroradiometrically measured cDOM over a wide range of salinities from the inner- to the outer-shelf surface waters and the suitability of using cDOM as the freshwater proxy. A conservative mixing of riverine DOC for the Laptev Sea has been reported,
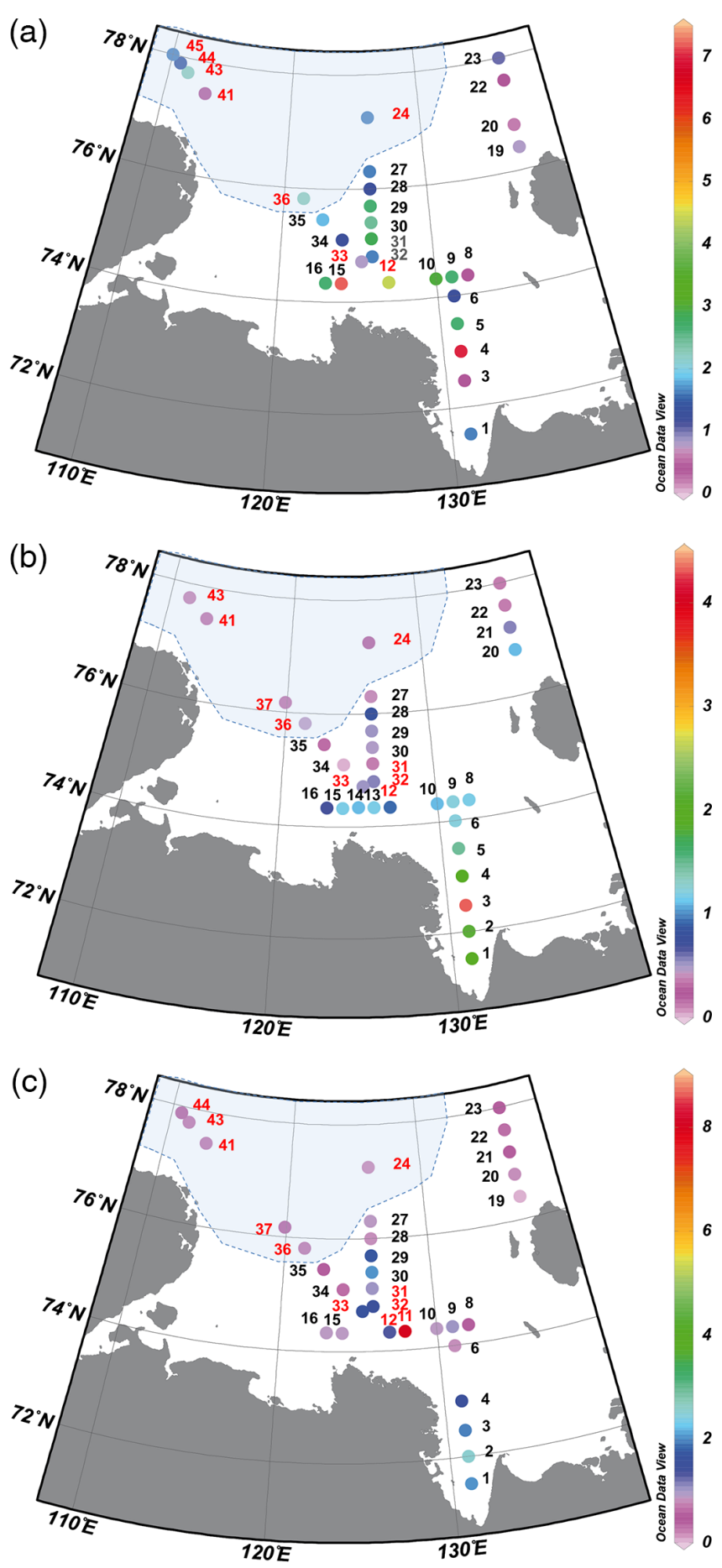

Figure 4. The overview on the TRANSDRIFT-XVII in-situ variables (a) SPM (mg L ${ }^{-1}$ ), (b) cDOM (absorption at $443 \mathrm{~nm}, \mathrm{~m}^{-1}$ ), and (c) $\mathrm{Chl} a\left(\mu \mathrm{gL} \mu \mathrm{g} \mathrm{L}^{-1}\right)$ (upper $2 \mathrm{~m}$ ). The concentrations are colour-coded. The numbers indicate the TRANSDRIFT sampling stations NE10-01 to NE10-45: black-numbered stations could be used for the match-up analyses; red-numbered stations could not be used due to cloud coverage (the blue line indicates continuous cloud coverage throughout most years in the northwestern Laptev Sea). Please note that not all variables could be covered at all stations. 
Table 2. Ranges of in situ measured variables (LENA2008, LENA2010, TRANSDRIFT) for different hydrogeographical regions.

\begin{tabular}{|c|c|c|c|c|c|}
\hline & $\begin{array}{l}\text { Lena River } \\
\text { mouth } \\
\text { (Bykovskaya } \\
\text { Channel) }\end{array}$ & $\begin{array}{l}\text { Coastal shallow } \\
\text { waters (mixed, } \\
<5-8 \mathrm{~m} \\
\text { water depth) }\end{array}$ & $\begin{array}{l}\text { Buor- } \\
\text { Khaya } \\
\text { Gulf }\end{array}$ & $\begin{array}{l}\text { Inner-shelf/ } \\
\text { anomalies }\end{array}$ & $\begin{array}{l}\text { Outer-shelf/ } \\
\text { anomalies }\end{array}$ \\
\hline $\begin{array}{l}\text { Salinity } \\
\text { (August 2008, August } \\
\text { and September 2010) }\end{array}$ & 0 & 0 & $0-6$ & $20-23$ & 32 \\
\hline $\begin{array}{l}\text { SPM (mg L } \\
\text { (August 2008, } \\
\text { September 2010) }\end{array}$ & $5-20$ & $3-18$ & $\begin{array}{l}01.5-3 / \\
5-6\end{array}$ & $1.5-2$ & $0.5-1$ \\
\hline $\begin{array}{l}\text { cDOM }\left(\mathrm{a}_{443} \mathrm{~m}^{-1}\right) \\
\text { (August } 2008 \text {, August } \\
\text { and September 2010) }\end{array}$ & $1.3-3.5$ & $2.5-4 / 7$ & $1.5-3$ & $1-1.5$ & $\begin{array}{l}0.4-0.6 / 1.7 \\
\mathrm{~N}^{\prime} \text { of Siberian } \\
\text { Islands }\end{array}$ \\
\hline $\begin{array}{l}\text { Chl } a\left(\mu \mathrm{g} \mathrm{L}^{-1}\right) \\
(\text { September } 2010)\end{array}$ & $\begin{array}{l}1-4 *(\text { spring } \\
\text { flood; Örek et } \\
\text { al., 2013) }\end{array}$ & - & $1.9-2.5$ & $\begin{array}{l}1 / 8(\mathrm{NE} 10-11) \\
\mathrm{N}^{\prime} \text { of Lena } \\
\text { River delta }\end{array}$ & $\begin{array}{l}0.5 / 1.5-2 \\
(\mathrm{NE} 10-29,30)\end{array}$ \\
\hline
\end{tabular}

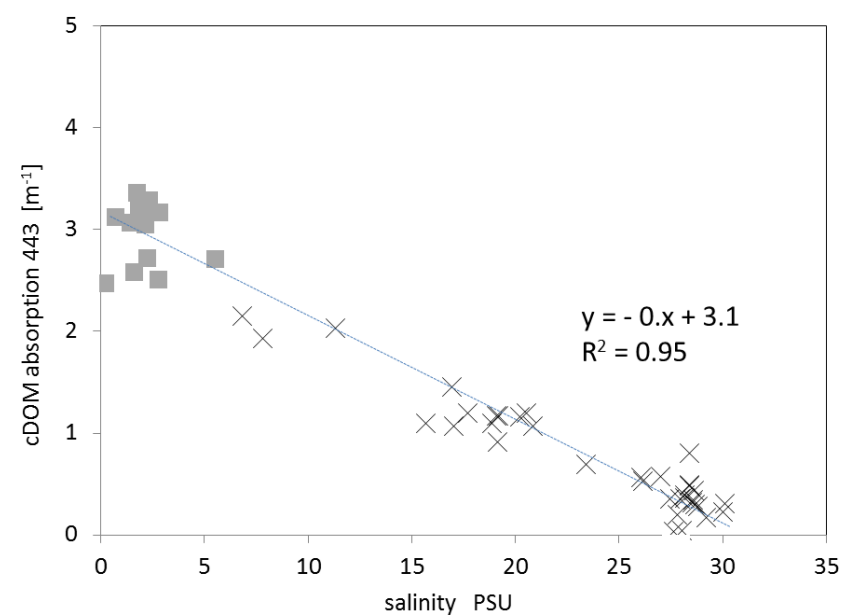

Figure 5. The relationship of the spectroradiometrically measured cDOM (absorption at $443 \mathrm{~nm}, \mathrm{~m}^{-1}$ ) vs. salinity on the L10 (squares) and TRANSDRIFT XVII (crosses) ship expeditions in 2010 shows the quasi-conservative mixing behaviour of cDOM over a wide range of salinities from the inner- to the outer-shelf surface waters.

e.g. in Kattner et al. (1999), Lobbes et al. (2000), Semiletov et al. (2011), and Semiletov et al. (this volume). In summary, cDOM background concentrations were high, including the offshore inner-shelf waters, and were connected to the freshwater signal. The cDOM concentrations of the Lena River in August 2008 and 2010 were of the same magnitude as the cDOM concentrations of the coastal waters in August 2008 and 2010, and in September 2010.

\subsubsection{Phytoplankton}

Investigations on phytoplankton (fluorimetrically derived from filters and in situ fluorescence-derived $\mathrm{Chl} a$ ) of multiyear TRANSDRIFT expedition data always report low to medium Chl $a$ concentrations in surface waters from onshore to offshore waters. Figure $4 \mathrm{c}$ and Table 2 give an overview on measured TRANSDRIFT Chl $a$ concentrations in September 2010. The concentrations of TRANSDRIFT Chl $a$ were from 1.9 to $2.5 \mu \mathrm{g} \mathrm{L}^{-1} \mathrm{Chl} a$ in the Buor-Khaya Gulf (samples 1-4). The east-west transect north of the Lena River delta (samples 8-16) showed transitional hydrological values and about $1 \mu \mathrm{g} \mathrm{L}^{-1} \mathrm{Chl} a$ at most stations. An exceptionally high Chl $a$ concentration occurred at station 11 with a maximum value of $8 \mu \mathrm{g} \mathrm{L}^{-1}$. In the outer-shelf waters Chl $a$ concentrations of the surface layer fluctuated around $0.5 \mu \mathrm{g} \mathrm{L}^{-1} \mathrm{Chl} a$. Samples 29-30 showed elevated Chl $a$ concentrations on the outer shelf with concentrations up to 1.5 to $2 \mu \mathrm{g} \mathrm{L}^{-1} \mathrm{Chl} a$ in marine waters with salinity of 32 .

\subsection{Evaluation of MERIS C2R parameters}

The match-up analyses in the Buor-Khaya Gulf show the technical limits of matching in optically highly heterogeneous and dynamic coastal waters. Therefore, no samples of the L08 expedition could be used for the match-up analyses. The match-up analyses using TRANSDRIFT data show more stable hydrodynamic conditions.

Coloured dissolved organic matter, cDOM: In situ TRANSDRIFT cDOM is underestimated as C2R_a_ys with $\mathrm{cDOM}=a_{\mathrm{ys}} \cdot 4.9\left(R^{2}=0.6\right)$. But we know from L8, L10 and TRANSDRIFT in situ data that high CDOM concentrations are widespread in coastal waters and on the inner shelf (Table 2). Total absorption, C2R_a_total, is a better-fitting 


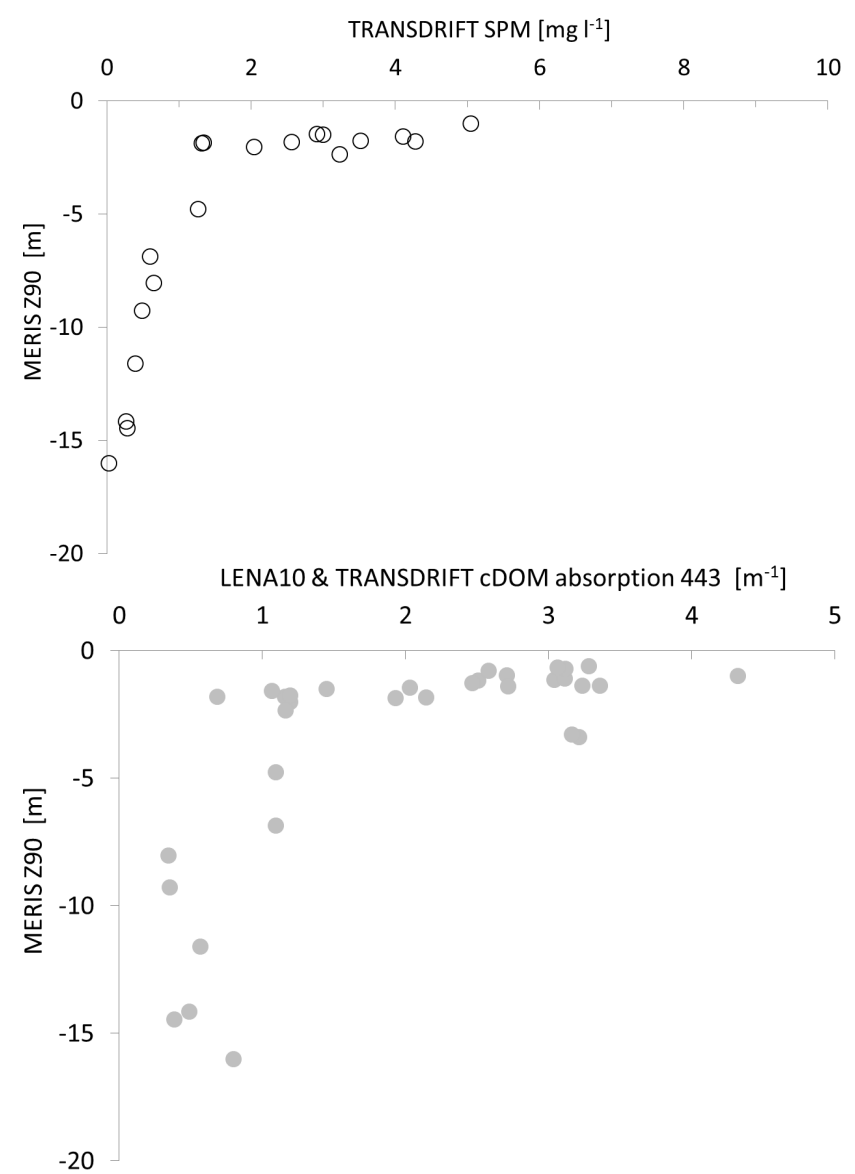

Figure 6. (a) In situ SPM (TRANSDRIFT data from 9 to 20 September 2010) vs. MERIS C2R_Z90 (calculated from the MERIS acquisition on 7 September 2010, $n=21)$. All selected MERIS values are without cloud contamination. (b) cDOM $_{443}$ (TRANSDRIFT \& LENA2010) vs. MERIS C2R_Z90. L10C2R_Z90 was taken from the MERIS concomitant acquisitions closest in time to the sampling: 3, 4 and 6 August 2010 were matched with LENA2010 $\mathrm{cDOM}_{443}, n=7$. TRANSDRIFTC2R_Z90 was taken from 7 September 2010 and matched with $\mathrm{cDOM}_{443}$ (9 to 20 September 2010) using all available pixels within relatively homogenous environments, but of satellite acquisition 2 to 5 days later, $n=22$.

parameter for $\mathrm{cDOM}$ with $\mathrm{cDOM}=a_{\text {total }} \cdot 1.5\left(R^{2}=0.6\right)$, and can be better used for visualizing cDOM. The match-up analyses show that the relationship of satellite-derived absorption versus in situ L10 cDOM is disturbed by the frequent frontal changes and the water colour dominating turbidity. The relationship of C2R_Z90 (indicative for transparency) versus in situ cDOM (L10 \& TRANSDRIFT) (e.g. Fig. 6b) shows that cDOM influences the transparency parameters (C2R_kmin, C2R_Z90) but is not as dominating as SPM (Fig. 6a).

Suspended particulate matter, SPM: The match-up analyses for cDOM and SPM versus C2R_kmin and C2R_Z90 show that a close correlation exists between transparency and SPM (e.g. Fig. 6a, C2R_Z90 versus SPM), indicating that the turbidity/particulate matter is the dominating optically visible aquatic component influencing the quality of satellite-derived parameters in turbid waters. There is a close correlation between the optical $\mathrm{C} 2 \mathrm{R}$ parameters connected to suspended matter (e.g. C2R_k $k_{\min }, \mathrm{C} 2 \mathrm{R} \_b b \_s p m$ (scattering of SPM), C2R_Z90, C2R_TSM) although there is a temporal difference between the in situ sampling and the MERIS acquisition on 7 September 2010. Figure 7a and $b$ show the relationship of TRANSDRIFT SPM versus the optical parameters $\mathrm{C} 2 \mathrm{R} \_k_{\min }$ and $\mathrm{C} 2 \mathrm{R} \_b b \_s p m$. The looser relationship between in situ TRANSDRIFT SPM and C2R_ $k_{\min }$ (Fig. 7a), also between the band ratio $R_{\mathrm{rs}} 778 / R_{\mathrm{rs}} 560$ and in situ TRANSDRIFT SPM (not shown) indicates the additional absorption by organic material at these sampling points. The relationships between TRANSDRIFT in situ SPM and the band ratio $R_{\mathrm{rs}} 778 / R_{\mathrm{rs}} 560$ are (i) $\mathrm{SPM}=35.1 \cdot \frac{R_{\mathrm{rs}} 778}{R_{\mathrm{rs}} 560^{2}} 0.3\left(R^{2}=0.77\right)$ for the linear relationship and (ii) $\mathrm{SPM}=-83.18 \cdot\left(\frac{R_{\mathrm{rs}} 778}{R_{\mathrm{rs}} 560}\right)^{2}+47.80$. $\frac{R_{\mathrm{r}} 778}{R_{\mathrm{rg}} 560}-0.7\left(R^{2}=0.78\right)$ for the polynomial relationship. The calculated SPM using the formula provided by Doxaran et al. (2012) shows a high intercept and a low linear slope, also indicating that the Laptev Sea shelf waters are more absorbing and darker then the Beaufort Sea surface waters: $\mathrm{SPM}_{\text {BeaufortSea }}=0.6 \mathrm{SPM}_{\mathrm{TRANSDRIFT}}+3.5$ $\left(R^{2}=0.73\right)$. C2R_bb_spm shows a close relationship with TRANSDRIFT SPM: SPM TRANSDRIFT $=52.31 \cdot \mathrm{bb} \_$SPM $0.09\left(R^{2}=0.98\right)$ (Fig. 7b). C2R_TSM is calculated based on the $\mathrm{C} 2 \mathrm{R}$ backscattering, bb_spm, showing a good performance, with $\mathrm{C} 2 \mathrm{R}$ TSM $=1.6 \mathrm{SPM}_{\mathrm{TRANSDRIFT}}+0.2\left(R^{2}=\right.$ 0.98 ) (Fig. 7c), however with an overall SPM overestimation with the factor around 1.7. Therefore, a regional SPM algorithm should use only the backscattering component that is not influenced by absorption. A preliminary calculation for the Laptev Sea using the TRANSDRIFT SPM data from 2010 gives $\mathrm{SPM}_{\mathrm{LaptevSea}}=50.78 \cdot b b_{\mathrm{spm}}\left(R^{2}=0.98\right)$ (Fig. 7c). Based on limited data, the regional SPM algorithm seems to perform for the Laptev Sea waters. This regional SPM algorithm can be consolidated in future with TRANSDRIFT expedition data from other years.

Chlorophyll, Chl $a$ : the group of inner-shelf and coastal stations display high Chl $a$ overestimation for all processing methods and algorithms. The outer-shelf stations in transparent waters display reasonable value ranges for most $\mathrm{Chl} a$ algorithms. Table 3 gives an overview on the relationships of the satellite-derived Chl $a$ vs. in situ TRANSDRIFT Chl $a$. Despite the in situ TRANSDRIFT Chl $a$ stations that could be used for the match-up analyses covering the inner- and the outer-shelf water types (Table 1) the value range is low from $\min 0.4 \mu \mathrm{g} \mathrm{L}^{-1}$ to $\max 2.5 \mu \mathrm{g} \mathrm{L}^{-1}$. Operational C2R_Chl $a$ values processed with the standard conversion factor of 21 are overestimated 15-fold in inner-shelf and coastal waters. In general, calculated C2R_Chl $a$ concentrations in the BuorKhaya Gulf show up to 20 to $30 \mu \mathrm{L} \mathrm{L}^{-1}$ C2R_Chl $a$ for all 


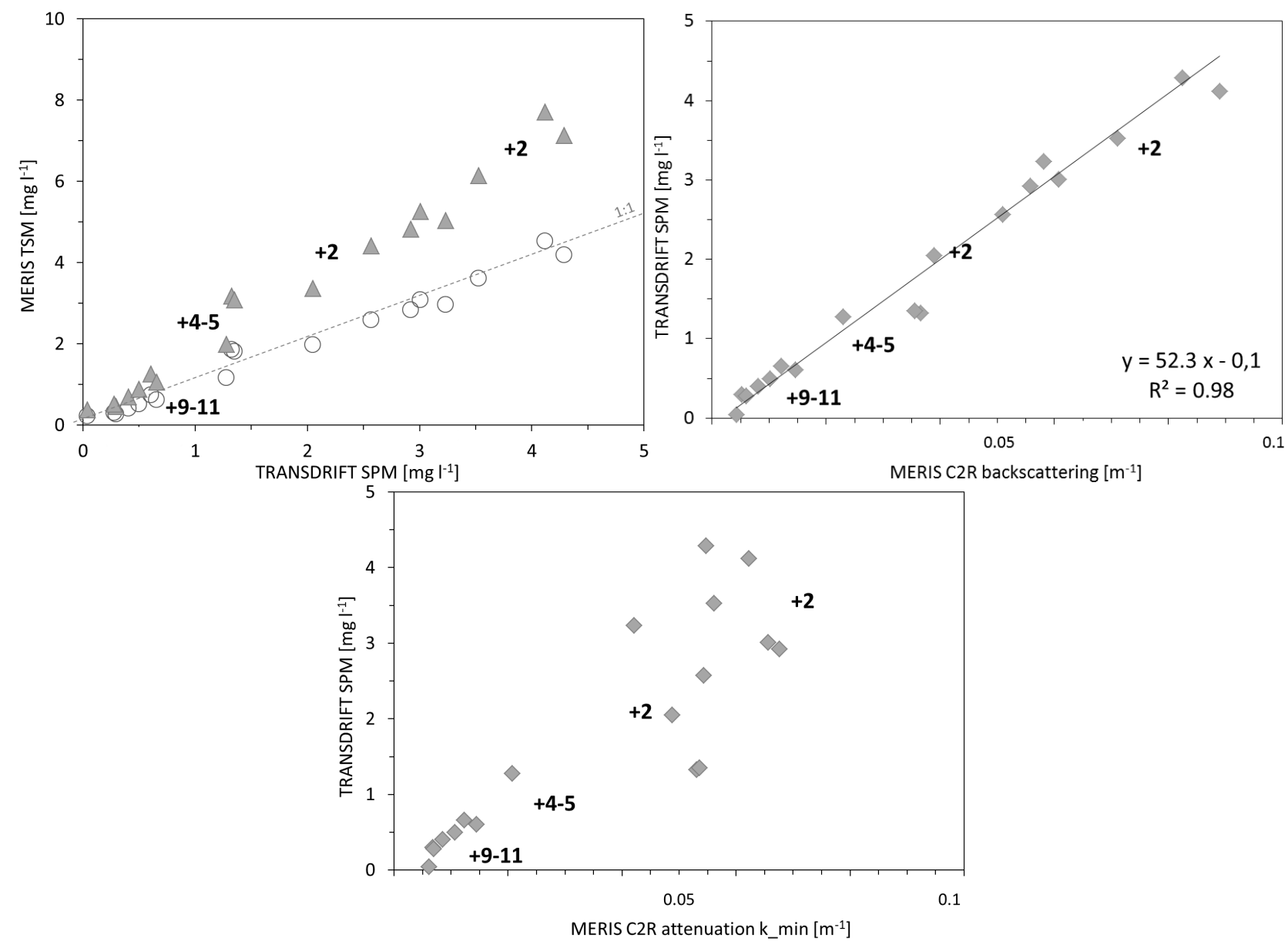

Figure 7. (upper left) Comparison of SPM (TRANSDRIFT data from 9 to 20 September 2010) vs. satellite-derived SPM (calculated from the MERIS acquisition on 7 September 2010, $n=19)$. SPM calculated as C2R_TSM is marked as triangles and shows the relationship $\mathrm{C} 2 \mathrm{R}$ TSM $=1.6 \mathrm{SPM}_{\mathrm{TRANSDRIFT}}+0.2\left(R^{2}=0.98\right) . \mathrm{SPM}$ calculated using the Laptev Sea algorithm $\left(\mathrm{SPM}=50.78 \cdot \mathrm{bb} \mathrm{spm}_{\mathrm{sp}}, R^{2}=0.98\right)$ is marked as open circles. Numbers indicate the temporal differences in days of the in situ sampling in relation to 7 September 2010. All selected MERIS values are without cloud contamination.(upper right) Comparison of in situ SPM (TRANSDRIFT data from 9 to 20 September 2010) vs. satellite-derived backscattering, C2R_bb_SPM $\left(\mathrm{m}^{-1}\right)$ (calculated from the MERIS acquisition on 7 September 2010, $n=19)$. SPM TRANSDRIFT $=52.31 \cdot$ bb_SPM $-0.09, R^{2}=0.98$.

(lower centre) Comparison of in situ SPM (TRANSDRIFT-XVII data from 9 to 20 September 2010) vs. satellite-derived attenuation, C2R $k_{\min }\left(\mathrm{m}^{-1}\right)$ (calculated from the MERIS acquisition on 7 September 2010 , MERIS TSM, $\left.n=19\right)$. SPM TRANSDRIFT $=5.15 \cdot k_{\min }-0.04$, $R^{2}=0.79$.

the years 2006 to 2011. A 10 -fold Chl $a$ overestimation is also characteristic of the MODIS Level-3 binned Chl $a$ products for September 2010 (9 km spatial pixel resolution). As an example, we also included the empirical operational Chl $a$ algorithms for MERIS, OC4Me, and the Arctic Chl $a$ algorithms OC4L and OC4P. OC4Me shows a 10 -fold overestimation for inner-shelf water pixels; the Arctic $\mathrm{Chl} a$ algorithms OC4L and OC4P show even higher Chl $a$ overestimation (Table 3). However, the inner-shelf waters are turbidityand cDOM-influenced Case- 2 waters with $R_{\mathrm{rs}} 670$ considerably higher than $0.005 \mathrm{sr}^{-1}$. In contrast, all satellite-derived Chl $a$ values of the more transparent outer-shelf water pixels show value ranges $<2 \mathrm{mg} \mathrm{L}^{-1} \mathrm{Chl} a$ (with the exception of the 3 -fold overestimation left in the case of the OC4L).
Even if C2R_Chl $a$ is processed using the regionally specific relationship for phytoplankton adapted to dark waters (due to cDOM absorption) derived from Örek et al. (this volume) with the much lower conversion factor of 7.8, the overestimation is still 5-fold for water pixels of the inner shelf. In the case of this dark-water-adapted processing the outer-shelf Chl $a$ values are underestimated by a factor of 0.6.

The strong absorption in the visible wavelength range that occurs due to the high cDOM concentrations is for global remote sensing products operationally attributed towards high $\mathrm{Chl} a$ concentrations. Based on this evaluation for the Laptev See we see that the overestimation of Chl $a$ occurs with all standard NASA and ESA processing algorithms because the standard assumption in all operational ocean colour 
Table 3. Relationships of satellite-derived Chl $a$ vs. in situ TRANSDRIFT Chl $a$, with the mean normalized bias (NB) (systematic error), the mean absolute difference (AD), and with the standard deviations (SD).

\begin{tabular}{lll}
\hline Algorithm & NB (mean, SD) & AD (mean, SD) \\
\hline C2R_Chl $a$ global vs. TRANSDRIFT-XVII Chl $a$ & & \\
all $(n=19)$ & $9.4,8.7$ & $9.6,8.6$ \\
inner-shelf waters $\left(R_{\mathrm{rs}} 670>0.005 \mathrm{sr}^{-1}, n=11\right)$ & $15.3,6.9$ & $15.3,6.9$ \\
outer-shelf waters $\left(R_{\mathrm{rs}} 670<0.005 \mathrm{sr}^{-1}, n=8\right)$ & $1.3,1.6$ & $1.6,1.3$ \\
C2R Chl $a$ Laptev Sea vs. TRANSDRIFT-XVII Chl $a$ & & \\
all $(n=19)$ & $3.2,3.5$ & $3.5,3.3$ \\
inner-shelf waters $\left(R_{\mathrm{rs}} 670>0.005 \mathrm{sr}^{-1}, n=11\right)$ & $5.6,2.8$ & $5.6,2.8$ \\
outer-shelf waters $\left(R_{\mathrm{rS}} 670<0.005 \mathrm{sr}^{-1}, n=8\right)$ & $-0.1,0.6$ & $0.6,0.3$ \\
OC4Me v6 Chl $a$ vs. TRANSDRIFT-XVII Chl $a$ & & \\
all $(n=19)$ & $6.4,5.5$ & $6.4,5.5$ \\
inner-shelf waters $\left(R_{\mathrm{rS}} 670>0.005 \mathrm{sr}^{-1}, n=11\right)$ & $10.0,4.6$ & $10.0,4.6$ \\
outer-shelf waters $\left(R_{\mathrm{rS}} 670<0.005 \mathrm{sr}^{-1}, n=8\right)$ & $1.5,1.5$ & $1.6,1.3$ \\
MODIS L3 binned Chl $a$ vs. TRANSDRIFT-XVII Chl $a$ & & \\
all $(n=12)$ & $7.7,3.1$ & $7.8,2.9$ \\
inner-shelf waters $(n=11)$ & $8.5,2.0$ & $8.5,2.0$ \\
outer-shelf waters $(n=1)$ & $-0.3,-$ & $0.3,-$ \\
OC4L vs. TRANSDRIFT-XVII Chl $a$ & & \\
all $(n=19)$ & $14.1,11.8$ & $14.1,11.8$ \\
inner-shelf waters $\left(R_{\mathrm{rs}} 670>0.005 \mathrm{sr}^{-1}, n=11\right)$ & $21.9,9.5$ & $21.9,9.5$ \\
outer-shelf waters $\left(R_{\mathrm{rS}} 670<0.005 \mathrm{sr}^{-1}, n=8\right)$ & $3.3,-2.9$ & $3.4,-2.8$ \\
OC4P vs. TRANSDRIFT-XVII Chl $a$ & & \\
all $(n=19)$ & $34.8,37.0$ & $35.0,36.8$ \\
inner-shelf waters $\left(R_{\mathrm{rS}} 670>0.005 \mathrm{sr}^{-1}, n=11\right)$ & $59.4,30.5$ & $59.4,30.5$ \\
outer-shelf waters $\left(R_{\mathrm{rs}} 670<0.005 \mathrm{sr}^{-1}, n=8\right)$ & $1.0,-1.8$ & $1.5,-1.3$ \\
\hline
\end{tabular}

algorithms contributes the main share of absorption towards the phytoplankton absorption. For Chl $a$-related applications, the absolute error becomes important. For the Siberian shallow shelf system, operational satellite-derived $\mathrm{Chl} a$ products should not be used.

\subsection{Spatio-temporel patterns of MERIS C2R variables}

The spatial distribution of different water types in the southern Laptev Sea can be visualized using the mapped MERIS $\mathrm{C} 2 \mathrm{R}$ variables. For the Laptev Sea region, the temporal resolution of usable MERIS satellite data time series lies between daily (in the case of low cloud coverage) and monthly resolution (in the case of high cloud coverage, as is common during the ice-free season).

The mapped optical and concentration parameters provide information on meso-scale spatial structures, such as meanders with amplitudes of 20 to $30 \mathrm{~km}$ and of filaments and eddies with diameters up to $100 \mathrm{~km}$ (e.g. Figs. 2a-c, 3, 8). Filaments of the turbid water type with low transparencies (low C2R_Z90, high C2R_ $k_{\min }$ ) and high SPM (high C2R_TSM) frequently developed within the Buor-Khaya Gulf. MERIS time series show that the filaments may be cut off the front and travel through the southern part of the Buor-Khaya Gulf. The temporal duration of all these spatially well-defined features is very short between one and a few days. During this time span, filaments and meanders may change abruptly (e.g. Fig. 2a-c).

Figure 8 shows C2R_TSM (mg L $\left.{ }^{-1}\right)$, C2R_Z90 (m), and C2R_absorption $\left(\mathrm{m}^{-1}\right)$ of a cloud-free MERIS acquisition on 25 September 2009. High absorption is widespread in the southern Laptev Sea. Intense meandering between turbid waters and less turbid waters is predominately found around the Lena River delta and in zones of shallow submarine banks. The range of C2R_TSM (2006 to 2010) in turbid regions shows concentrations from 5 to $12 \mathrm{mg} \mathrm{L}^{-1}$ and a calculated $Z_{\mathrm{Eu}}$ of maximal $5 \mathrm{~m}$. Calculated $Z_{\mathrm{Eu}}$ outside the turbid water zones in the centre of the Buor-Khaya Gulf indicate a $10 \mathrm{~m}$ euphotic water layer. In August 2010, an irregularly shaped, transparent eddy system showed up in the central Buor-Khaya Gulf (Fig. 2b, c) with $13 \mathrm{~m}$ of the euphotic depth layer, $Z_{\mathrm{Eu}}$.

High turbidity is regularly visible on the submarine banks around the Lena River delta and in the vicinity around the New Siberian Islands. Frequently, the turbidity zones 
a)

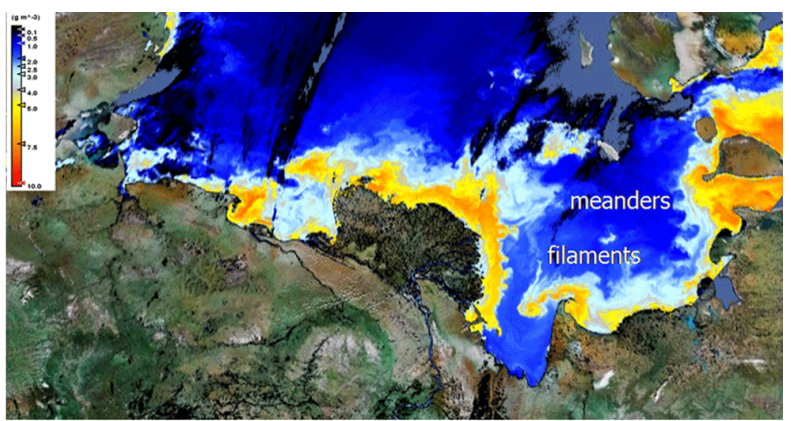

b)

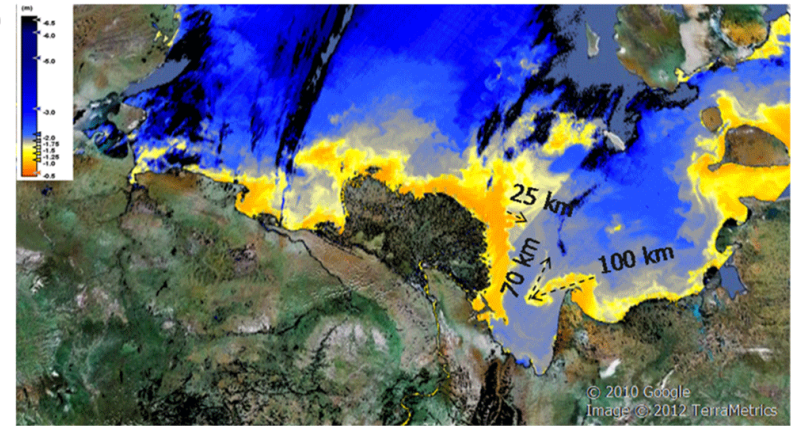

c)

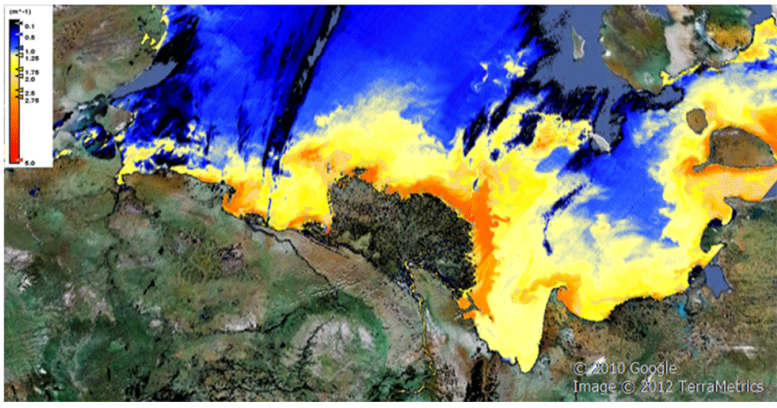

Figure 8. MERIS colour-coded maps of the southern Laptev Sea, on 25 September 2009 at 11:55 (local time) visualize the fields of meanders and filaments. The mapped C2R parameters are (a) MERIS C2R_TSM $\left(\mathrm{g} \mathrm{m}^{-3}\right)$, (b) MERIS C2R_Z90 (m), and (c) MERIS C2R_absorption $\left(\mathrm{m}^{-1}\right)$.

considerably enlarge along the coastlines, and on the eastern Siberian shallow shelf. Turbidity events also occur above the shallows in the central southern Laptev Sea. The turbidity zones suggest that remobilization of sea surface sediments and resuspension events occur in such shallow regions.

We also investigated whether the outline of a freshwater plume is visible in the mapped MERIS C2R variables, expecting to detect high SPM, high attenuation and absorption and low transparencies. Unfortunately, the event of the spring freshet is mostly hidden for optical remote sensing applications under the continuous cloud coverage in the months of June and early July. From 2006 to 2011, only very few acquisitions in early summer, 1 July 2009 and 3 July 2011, capture the spring freshet. The Lena River outflow during the spring freshet appears onto the surrounding ice-free waters in early July. During the spring freshet, elevated turbidity-related pa- rameters and absorption with the spatial outline of a plume would be visible only in the very rare case of no sea ice coverage, such as was the case in July 2011. In all other investigated years there was still sea ice coverage around the Lena River delta in June and early July with the Lena River outflow visible on top of the sea ice.

After the high flood conditions during summer months, from mid-July until the end of September in all investigated years, the Lena River freshwater plume seems to be not outlined and detectable as a spatially outlined plume structure. Instead, on the wide submarine bank around the Lena River delta and on the shallows directly northeast of the Lena River delta, turbid waters are regularly visible. Northeast of the Lena River delta at the outlets of the Lena River branches, regularly, meanders and filaments, sometimes of a dipole type (with meander crests and filaments developing in more than one direction), are developing and being pushed outwards. Also west of the Yana River delta frequently occurring and changing meanders and filaments indicate frontal instabilities.

L10 expedition data show that a strong stratification with a mixed layer of 5 to $8 \mathrm{~m}$ depth existed in the Buor-Khaya Gulf in the beginning of August 2010. Brackish surface water (salinity $>8$ ) occurred only at the two northeasternmost stations outside the Buor-Khaya Gulf (Fig. 2a). The sampling on the onshore transects (stations 15 to 18) on 1 August 2010 along the Lena River delta proves a fully mixed layer of high turbidity. This turbidity zone above the submarine shallow Lena River delta banks incorporates both freshwater surface stations (salinity $<1$ ) and freshwater-influenced stations but not yet brackish-water salinities (salinity $<5$ ). The freshwater-dominated salinities $<5$ can be found within a wide range of turbidity. This indicates that the Lena River freshwater signal is not directly linked to turbidity in coastal waters. It is an important finding that the riverine turbidity of the Lena River is optically hidden in the turbidity of coastal waters due to resuspension above the shallow submarine banks.

\section{Value and validity of ocean colour applications for the Siberian shelf}

Ocean colour remote sensing reveals how highly timedependent and turbulent the shallow Siberian inner-shelf and coastal waters are. The spatial and temporal undersampling by ground-based observing tools causes data gaps. Highly dynamically changing spatial patterns and complex features are usually averaged out through the data interpolation processes and cannot be mapped as the temporal snapshots they are. In the following sections we discuss the value and validity of the ocean colour visualization for biogeoscientific applications: (i) the regional validity of satellite-derived variables; (ii) the hydrographic pattern of meanders, eddies and filaments that indicate a widespread lateral advection in the 
sea-ice-free season; and (iii) resuspension zones that potentially indicate vertical transport pathways of nutrients, carbon, sediments and heat.

\subsection{Regional validity of operational products}

The first evaluation experiments show that the turbidityrelated variables can be used reliably to trace the surface hydrodynamics of the Laptev Sea region. However, care must be taken when using operational Chl $a$ products for the Siberian inner-shelf regions. Bio-optical measurements from Örek et al. (this volume) in the Lena River waters showed that the specific phytoplankton absorption coefficient is around three times higher and more effective than global mean phytoplankton absorption coefficients. The authors discuss the difficulty of the calculation of phytoplankton from the waterleaving reflectances because phytoplankton absorption contributed only $<10 \%$ to the overall absorption. We incorporated the regionally specific phytoplankton absorption capacity in the $\mathrm{C} 2 \mathrm{R}$ processing by using the conversion factor from phytoplankton absorption to Chl $a$ of 7.8 (Örek et al., this volume) instead of using the standard conversion factor of 21. However, the elevated cDOM concentrations still lead to a 5-fold Chl $a$ overestimation for inner-shelf water pixels. All global ESA and NASA Chl $a$ products show an overestimation by at least a factor of 10 for the coastal and innershelf waters. This regional overestimation is the highest reported to date for Arctic coastal waters, but also the cDOM inner-shelf concentrations in the Laptev Sea are the highest reported for Arctic coastal waters.

Vetrov et al. (2008) discussed a Chl $a$ overestimation factor of around 5 for the Laptev Sea, however, the authors describe the large difficulties of their match-up analyses for the inner-shelf area due to cloudiness. It remains unclear how many and which samples were used to estimate the factor. Matsuoka et al. (2007, 2012a, b) report that ocean colour Chl $a$ retrievals for the western Beaufort and Chukchi seas were within 25 and $30 \%$ accuracy; Wang and Cota (2003) report an overestimation factor of 1.5 for this region. However, for the southeastern Beaufort Sea cDOM background concentrations are higher on the inner shelf. Mustapha et al. (2012) evaluated operational Chl $a$ products of various ocean colour sensors using the large in situ data set of the Canadian Arctic Shelf Exchange Study (CASES). The authors report an overestimation by a factor of 3 to 5 , the highest overestimation being based on match-up analyses reported they found for coastal waters under a freshwater influence. Hessen et al. (2010) describe Chl concentrations of an order of magnitude too high for LevenbergMarquadt-based processed MODIS products from summer 2003 (Pozdnyakov et al., 2005) covering the southern Kara Sea with the Ob Estuary. That may technically also be due to the high concentrations of dissolved organic matter for the coastal Kara Sea waters with reported in situ concentrations of $>5 \mathrm{mg} \mathrm{L}^{-1}$ DOC (Hessen et al., 2010). Mustapha et al. (2012) in their study of the southeastern Beaufort Sea also assume that the widespread higher particle background in Beaufort Sea coastal waters increases the backscattering and potentially contributes to the large overestimation of operational Chl $a$ products.

\subsection{Widespread lateral surface advection in the sea ice-free season}

Wegner et al. (this volume) discuss how the freshwater from the Lena River and other Siberian rivers is widespread on the Laptev Sea shelf. The authors describe a SPM-enriched freshwater surface layer up to latitude of $76.8^{\circ} \mathrm{N}$, north of the Lena River delta, and $77.8^{\circ} \mathrm{N}$ on the eastern shelf in September 2008. The year 2008 was an abnormal one of anti-cyclonic atmospheric circulation pattern with dominating offshore winds. In September 2007, a quasi-normal year of cyclonic atmospheric circulation pattern, with dominating onshore winds and eastward, non-cross-shelf transport of the riverine freshwater, the authors describe SPM-enriched freshwater having been measured up to latitude of $75^{\circ} \mathrm{N}$. The authors showed that this spatially contrasting freshwater transport could also be made visible in the mapped MERIS C2R parameters: in 2008, the outer-shelf areas show less transmissivity (higher C2R_k $k_{\min }$, lower C2R_Z90) compared to more transparent waters on the outer shelf in 2007 (Wegner et al., this volume).

However, we cannot observe a well-defined Lena River plume in the distribution of turbidity-related and absorptionrelated C2R variables. Multi-year expedition data show that the southern Laptev Sea is characterized by a high freshwater signal and background cDOM concentrations (e.g. a $443_{\text {cDOM }}$ range in the Buor-Khaya Gulf is 2 to $2.5 \mathrm{~m}^{-1}$ ) and that cDOM and SPM of the Lena River in August are of the same magnitude as in the coastal waters surrounding the Lena River delta in the August and September months. That the magnitude of concentrations is the same in the BuorKhaya Gulf compared to Lena riverine waters is also a finding related to $\mathrm{POC}$, nutrients $\left(\mathrm{NO}_{3}, \mathrm{PO}_{4}\right), p \mathrm{CO}_{2}$ and oxygen saturation from multi-year expedition data (Semiletov et al., 2013).

Due to continuous cloud coverage north of $75^{\circ} \mathrm{N}$ at a longitude of $130^{\circ} \mathrm{E}$ and westwards of it, the most transparent, lowest CDOM and SPM water type is only visible within a few small cloud-free patches in the MERIS time series. Regularly, the high optical contrast between highcDOM freshwater-influenced surface waters and low-cDOM marine-background waters seems to lie northwards of the cloud-free mapped areas always under continuous cloud coverage.

The horizontal meander fields and filament fields in the southern Laptev Sea suggest that a high frontal instability is continuously being generated. The frontal instability may be shed from the Lena River inflow and from unstable coastal currents. Meanders, filaments and eddies horizontally 
transport material within the surface water layer due to hydrodynamical equilibrium forces. Hydrodynamical model simulations and mooring current measurements show that these horizontal structures also provide vertical motion and indicate the vertical mixing of a surface layer (e.g. Chao and Shaw, 2002; Ralph, 2002; Sutherland et al., 2011; Fong et al., 2002). The rich hydrographic spatio-temporal pattern of filament fields, meander fields and eddies suggests that they carry chemical and biological fields and could trigger a high patchiness of phytoplankton in the Laptev See region. Kraberg et al. (this volume) discuss a high spatial heterogeneity in phytoplankton composition in August 2010 in the Buor-Khaya Gulf probably resulting from the out-flushing from the Lena River.

\subsection{Resuspension zones above shallows}

The visualization of resuspension events in the mapped MERIS C2R variables highlights vertical mixing events down to the sea bottom of shallow submarine banks in the southern Laptev Sea region. The depth of the mixing zone is related to the regional wind fields, with the turbidityinfluenced zones growing larger in response to strong and frequently changing winds. This can be frequently observed above the submarine shallows and along the deeper eastern coastline of the Buor-Khaya Gulf. Such is the case in early August 2010 with transparent coastal waters along the eastern Buor-Khaya coast. The transparent coastal waters indicate no intense resuspension within this region characterized by a steeper submarine slope and a near-shore bathymetry below $5 \mathrm{~m}$. The eastern coast delivers freshwater sources from the eastern side (e.g. station 8 , salinity $<1$ ). The turbid river inflow into transparent coastal waters can even optically be traced, e.g. MERIS acquisition on 8 August 2010 (Fig. 9a).

After several storm events (Günther et al., 2013b) in the southern Laptev Sea region in August and September 2010, the mixed upper layer became deeper and the mixed layer went down to a depth of at least 10 to $12 \mathrm{~m}$ in September 2010, as it was measured on the TRANSDRIFT XVII expedition. With a mixed upper layer reaching down to the seabed bottom of 10 to $12 \mathrm{~m}$, resuspension occurs. The MERIS acquisition on 27 August 2010 makes resuspension visible in wide areas on the inner shelf and also along the eastern coastline of the the Buor-Khaya Gulf (Fig. 9b). The high spatial resolution of the RapidEye satellite data $(5 \mathrm{~m}$ per pixel at nadir) on 8 and 27 August 2010 confirms the hydrodynamic interpretation of the coarser-scale MERIS satellite data (Fig. 9a, b). The resuspension events along the eastern coastline of the Buor-Khaya Gulf indicate intense vertical mixing down to a submarine bottom depth of a minimum of $10 \mathrm{~m}$. a)

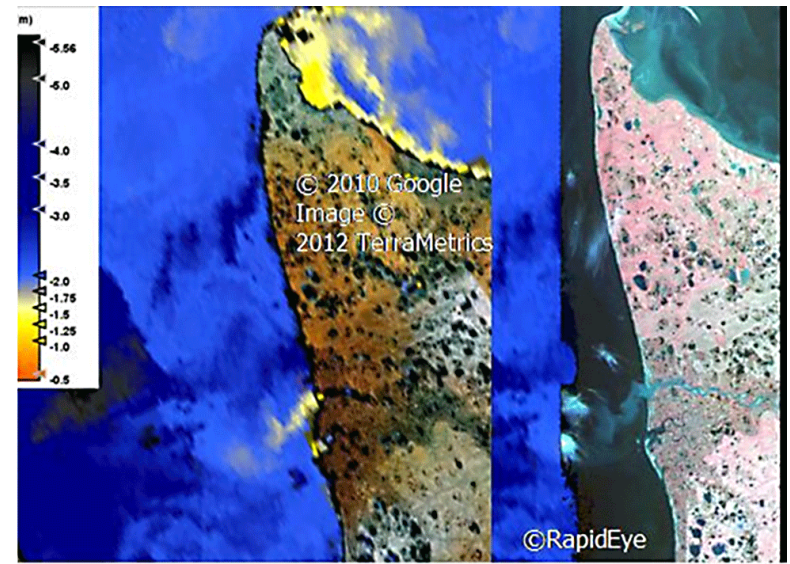

b)

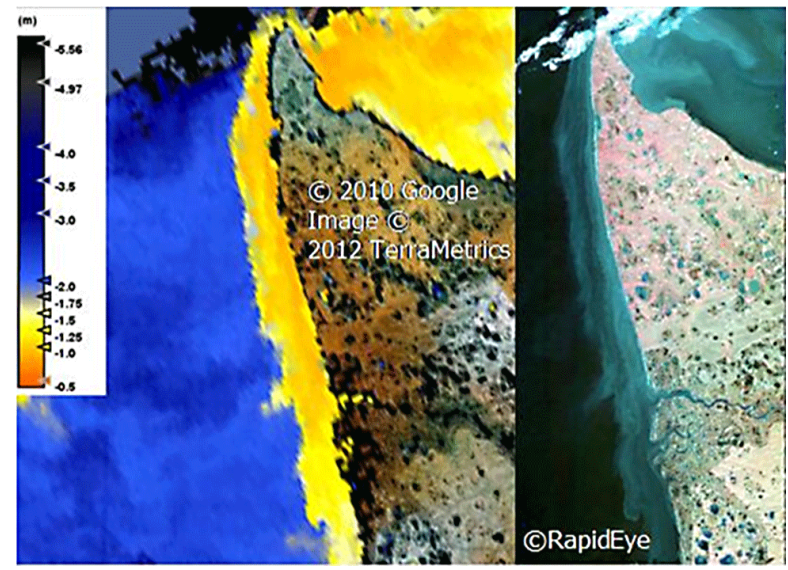

Figure 9. MERIS satellite data (a: 8 August 2010; b: 27 August 2010) and RapidEye satellite data (a: 8 August 2010; b: 27 August 2010) of the eastern Buor-Khaya Gulf coast. The RapidEye falsecolour NIR composite has a spatial resolution of $6.5 \mathrm{~m}$. The colourcoded MERIS map shows C2R_Z90 $\left(\mathrm{m}^{-1}\right)$. At the beginning of August the coastal waters along the eastern Buor-Khaya Gulf coast show a high transparency, and a spatially confined turbid river inflow into the Buor-Khaya Gulf is visible. After storm events at the end of August 2010 a turbidity zone along the eastern Buor-Khaya Gulf coast above the shallow submarine slope is visible.

Charkin et al. (2011) state that, for the shallow Laptev Sea, the impacted zone by resuspension events should be on average down to the $10 \mathrm{~m}$ bathymetry (with an estimation of average wave height of $1 \mathrm{~m}$ ), accounting for the only short duration of strong waves. They describe how the dominating sand to sandy silt fraction that they found on the shallows supports the theory of vertical mixing events down to these bathymetric depths. Gavrilov et al. (2003) cite observations made on Russian seismic expeditions during the summer months that prove that high local turbidity can be observed above these submarine banks (in Lisitsin et al., 2000; Dmitrenko et al., 2001). 
Wegner et al. (this volume) report that data based on current speeds of the ANABAR mooring station $\left(74^{\circ} 30^{\prime} \mathrm{N}\right.$, $127^{\circ} 20^{\prime} \mathrm{E}$ ) in the Laptev Sea show that within 2 years during one time period following a storm event currents exceeded the critical shear stress velocity, and therefore resuspension of bottom material could take place even down to depths of around $30 \mathrm{~m}$. Also Vonk et al. (2012) confine a potential sedimentational regime to below $30 \mathrm{~m}$ bathymetric depth, relating to the occurrence of pelite below those depths.

To facilitate further understanding of the processes of deposition of terrestrial material on the Laptev Sea and eastern Siberian shelf regions, ocean colour remote sensing may provide the necessary information on the submarine depths of regular submarine seabed erosion and entrainment and on the submarine depths where abrasion only occurs when caused by strong storm events.

\section{Conclusions}

After the event of the spring freshet, the Lena River flows out into coastal waters of similar concentrations of SPM and cDOM during mid-July to September. The similar ranges of SPM are due to the vertical mixing down to the bottom, and therefore resuspension occurs above the shallow submarine bank around the Lena River delta. Widespread vertical mixing down to the sea bottom, and therefore resuspension, occurs on the numerous submarine shallows in the Laptev Sea.

A first evaluation of the value ranges of satellite-derived parameters for the Laptev Sea shelf is presented. Match-up analyses were constrained by high cloud coverage. The relationship of satellite-derived turbidity-related parameters versus in situ TRANSDRIFT SPM shows that the backscattering coefficient C2R_bb_spm can be used to derive a Laptev-Seaadapted SPM algorithm. Satellite-derived Chl $a$ estimates are highly overestimated by a minimum factor of 10 if applied to the inner-shelf region due to elevated concentrations of terrestrial organic matter. The shallow Siberian shelf region requires bio-optical measurement campaigns to develop regionally adapted algorithms for cDOM, SPM and Chl $a$.
The high turbidity above shallows and the widespread high cDOM concentrations is the reason why we cannot outline a Lena River plume in the distribution of turbidity-related and absorption-related satellite-derived parameters. The spatial turbidity pattern well visible in the mapped remote sensing parameters provides the information on how turbulent and hydrodynamically complex the southern Laptev Sea region is. The mapped optical parameters show that the Laptev Sea is dominated by frontal meanders with amplitudes up to $30 \mathrm{~km}$ and eddies and filaments with horizontal scales up to $100 \mathrm{~km}$ that prevail throughout the sea-ice-free season. The resuspension above the submarine banks and the frontal meanders, filaments and eddies indicate enhanced vertical mixing being widespread on the inner shelf. The vertical mixing events seem frequently to reach down to submarine depths of a minimum of $10 \mathrm{~m}$.

The spatio-temporal pattern of the ocean colour parameters indicate a strong potential for lateral advection of terrestrial (dissolved and fine particulates) and living biological material during the ice-free season. To date, the recognized lateral pathways in the Laptev Sea are known to function by transport within and on the sea ice (Eicken et al., 1997, 2000) and via the bottom nepheloid layer (Wegner et al., 2003, 2005). It is a new finding for the Laptev Sea that numerous frontal instabilities are made visible and that strong lateral surface advection may occur during the ice-free season. The meanders, filaments and eddies revealed by the ocean colour parameters indicate lateral transportation pathways for terrestrial material but also vertical blockades. 


\section{Appendix A: Ocean Colour algorithms}

(i) Eutrophic depth, $Z_{\mathrm{Eu}}$ is calculated from the $\mathrm{C} 2 \mathrm{R}$ processed C2R_k $k_{\min }$ as

$Z_{\mathrm{Eu}}(\lambda)=\frac{4.6}{k_{\min }(\lambda)}, \mathrm{m}$.

(ii) The Mackenzie/Beaufort Sea SPM algorithm (Doxaran et al. 2013) is calculated using the band ratio of the C2Rprocessed $R_{\mathrm{rs}}\left(\mathrm{sr}^{-1}\right)$ of MERIS band 12 (centre wavelength: $778 \mathrm{~nm}$ ) and MERIS band 5 (centre wavelength: $560 \mathrm{~nm}$ ):

$$
\begin{aligned}
\mathrm{SPM}_{\text {Mackenzie }} & =95.883 \cdot\left(R_{\mathrm{rs}} 778 / R_{\mathrm{rs}} 560\right)^{2} \\
& +12.733 \cdot\left(R_{\mathrm{rs}} 778 / R_{\mathrm{rs}} 560\right)+3.2567 .
\end{aligned}
$$

(iii) The MERIS Ocean Colour algorithm, newest version, OC4Mev6, is calculated using the band ratio of the C2Rprocessed $R_{\mathrm{rS}}\left(\mathrm{sr}^{-1}\right)$ of MERIS band 4 (centre wavelength: $510 \mathrm{~nm}$ ) and MERIS band 5 (centre wavelength: $560 \mathrm{~nm}$ ):

$$
\begin{aligned}
\mathrm{OC} 4 \mathrm{Me} & =\exp 10\left(0.3252-2.767 \cdot \log 10\left(R_{\mathrm{rs}} 510 / R_{\mathrm{rs}} 560\right)\right. \\
& +2.44 \cdot \log 10\left(R_{\mathrm{rs}} 510 / R_{\mathrm{rs}} 560\right)^{2} \\
& -1.128 \cdot \log 10\left(R_{\mathrm{rs}} 510 / R_{\mathrm{rs}} 560\right)^{3} \\
& \left.-0.499 \cdot \log 10\left(R_{\mathrm{rs}} 510 / R_{\mathrm{rs}} 560\right)^{4}\right) .
\end{aligned}
$$

(iv) The OC4L (Cota et al., 2004) is calculated using the band ratio of the C2R-processed $R_{\mathrm{rs}}\left(\mathrm{sr}^{-1}\right)$ of MERIS band 4 (centre wavelength: $510 \mathrm{~nm}$ ) and MERIS band 5 (centre wavelength: $560 \mathrm{~nm}$ ):

$\mathrm{OC} 4 \mathrm{~L}=\exp 10\left(0.592-3.607 \cdot \log 10\left(R_{\mathrm{rs}} 510 / R_{\mathrm{rs}} 560\right)\right)$.

(v) The OC4P (Wang and Cota, 2003) is calculated using the band ratio of the C2R-processed $R_{\mathrm{rS}}\left(\mathrm{sr}^{-1}\right)$ of MERIS band 4 (centre wavelength: $510 \mathrm{~nm}$ ) and MERIS band 5 (centre wavelength: $560 \mathrm{~nm}$ ):

$$
\begin{aligned}
\text { OC4P } & =\exp 10\left(0.271-0.628 \cdot \log 10\left(R_{\mathrm{rs}} 510 / R_{\mathrm{rs}} 560\right)\right. \\
& +2.629 \cdot \log 10\left(R_{\mathrm{rs}} 510 / R_{\mathrm{rs}} 560\right)^{2} \\
& +0.6094 \cdot \log 10\left(R_{\mathrm{rs}} 510 / R_{\mathrm{rs}} 560\right)^{3} \\
& \left.-0.453 \cdot \log 10\left(R_{\mathrm{rs}} 510 / R_{\mathrm{rs}} 560\right)^{4}\right) .
\end{aligned}
$$


Acknowledgements. This work is supported by the German Science Foundation (DFG 4575) and the Helmholtz Climate Initiative REKLIM (Regionale Klima"anderungen/Regional climate change). The Russian-German LENA08 and LENA10 ship expeditions are supported and organized by the AWI (Germany) and the Arctic and Antarctic Research Institute (AARI; St. Petersburg, RU). The vessels used were the Russian river vessel Puteyski 405 in 2008 and 2010, and PTS TB-0012 in the Buor-Khaya Gulf in 2010. The TRANSDRIFT expedition is an integral part of the joined Russian-German project "Laptev Sea System" funded by the German Federal Ministry for Education and Research and the Russian Ministry of Education and Science. The vessel used for the TRANSDRIFT-XVII expedition in September 2010 was the RV NIKOLAY EVGENOV. We thank the captains and the crews for their support.

We are very much in debt to Ruth Flerus, AWI/GEOMAR, who sampled and prepared the cDOM samples at the LENA2010 ship expedition. We thank the OSL, St. Petersburg (RU), specifically Elena Dobrotina, for the support for the cDOM measurements from all expeditions. We thank Bennet Juhls, University of Kiel/GEOMAR, for the NCEP wind analyses.

The ESA ENVISAT project (MERIS-ID 5504) granted the used MERIS data. We thank the German Aerospace Agency (DLR) for providing RapidEye data from the RESA (RapidEye Science Archive) programme (grant number 424 Geomonitoring PROGRESS). BEAM-VISAT is open-source software initiated by ESA and developed and realized by Brockmann Consult (DE). The C2R processor has been developed as a joint effort between the HZG Research Centre, Institute for Coastal Research, and Brockmann Consult, under ESA contract.

Edited by: I. Bussmann

\section{References}

Aagaard, K. and Armack, E.: The role of sea ice and other fresh water in the Arctic circulation, J. Geophys. Res., 94, 14485-14489, 1989.

Antoine, D., Hooker, S. B., Bélanger, S., Matsuoka, A., and Babin, M.: Apparent optical properties of the Canadian Beaufort Sea Part 1: Observational overview and water column relationships, Biogeosciences, 10, 4493-4509, doi:10.5194/bg-10-4493-2013, 2013.

Bauch, D., Dmitrenko, I. A., Wegner, C., Hölemann, J. A., Kirillov, S. A., Timokhov, L. A., and Kassens, H.: Exchange of Laptev Sea and Arctic Ocean halocline waters in response to atmospheric forcing, J. Geophys. Res., 114, 2156-2202, 2009.

Bélanger, S., Babin, M., and Larouche, P.: An empirical ocean color algorithm for estimating the contribution of chromophoric dissolved organic matter to total light absorption in optically complex waters, J. Geophys. Res., 113, C04027, doi:10.1029/2007JC004436, 2008.

Bélanger, S., Cizmeli, S. A., Ehn, J., Matsuoka, A., Doxaran, D., Hooker, S., and Babin, M.: Light absorption and partitioning in Arctic Ocean surface waters: impact of multiyear ice melting, Biogeosciences, 10, 6433-6452, doi:10.5194/bg-10-6433-2013, 2013.
Chao, S.-Y. and Shaw, P. T.: Nonhydrostatic aspects of coastal upwelling meanders and filaments off eastern ocean boundaries, Tellus A, 54, 63-75, 2002.

Charkin, A. N., Dudarev, O. V., Semiletov, I. P., Kruhmalev, A. V., Vonk, J. E., Sánchez-García, L., Karlsson, E., and Gustafsson, Ö.: Seasonal and interannual variability of sedimentation and organic matter distribution in the Buor-Khaya Gulf: the primary recipient of input from Lena River and coastal erosion in the southeast Laptev Sea, Biogeosciences, 8, 2581-2594, doi:10.5194/bg8-2581-2011, 2011.

Cota, G. F., Wang, J., and Comiso, J. C.: Transformation of global satellite chlorophyll retrievals with a regionally tuned algorithm, Remote Sens. Environ., 90, 373-377, 2004.

Dmitrenko I. A, Hoelemann, J., Kirillov, S. A, Wegner, C., Gribanov, V. A, Berezovskaya, S. L., and Kassens, H. M.: Thermal regime of the bottom water layer in the Laptev Sea and determining processes, Kriosfera Zemli, 5, 40-55, 2001 (in Russian).

Dmitrenko, I. A., Kirillov, S. A., Eicken, H., and Markova, N.: Wind-driven summer surface hydrography of the eastern Siberian shelf, Geophys. Res. Lett., 32, L14613, doi: 10.1029/2005GL023022, 2005.

Doerffer, R. and Schiller, H.: The MERIS case 2 water algorithm, Int. J. Remote Sens., 28, 517-535, 2007.

Doerffer, R. and Schiller, H.: MERIS Regional Coastal and Lake Case 2 Water Project Atmospheric Correction, GKSS-KOFMERIS-ATBD01, Institute for Coastal Research, GKSS Research Center, Geesthacht, 42 pp., 2008.

Doxaran, D., Ehn, J., Bélanger, S., Matsuoka, A., Hooker, S., and Babin, M.: Optical characterisation of suspended particles in the Mackenzie River plume (Canadian Arctic Ocean) and implications for ocean colour remote sensing, Biogeosciences, 9, 32133229, doi:10.5194/bg-9-3213-2012, 2012.

Eicken, H., Reimnitz, E., Alexandrov, V., Martin, T., Kassens, H., and Viehoff, T.: Sea-ice processes in the Laptev Sea and their importance for sediment export, Cont. Shelf Res., 17, 205-233, 1997.

Eicken, H., Kolatschek, J., Freitag, J., Lindemann, F., Kassens, H., and Dmitrenko, I.: Identifying a major source area and constraints on entrainment for basin-scale sediment transport by Arctic sea ice, Geophys. Res. Lett., 27, 1919-1922, 2000.

Fedorova, I., Chetverova, A., Bolshiyanov, D., Makarov, A., Boike, J., Heim, B., Morgenstern, A., Overduin, P., Wegner, C., Kashina, V., Eulenburg, A., Dobrotina, E., and Sidorina, I.: Lena Delta hydrology and geochemistry, Biogeosciences Discuss., 10, 20179 20237, doi:10.5194/bgd-10-20179-2013, 2013 (this volume).

Fong, D. A. and Geyer, W. R.: The Alongshore Transport of Freshwater in a Surface-Trapped River Plume, J. Phys. Oceanogr., 32, 957-972, 2002.

Gavrilov, A. V., Romanovskii, N. N., Romanovsky, V. E., Hubberten, H.-W., and Tumskoy, V. E.: Reconstruction of Ice Complex Remnants on the Eastern Siberian Arctic Shelf, Permafrost Periglac., 14, 187-198, 2003.

Gordeev, V. V., Martin, J.-M., Sidorov, I. S., and Sidorova, M. N.: A reassessment of the Eurasian river input of water, sediment, major elements and nutrients to the Arctic Ocean, Am. J. Sci., 296, 664-691, 1996.

Günther, F., Overduin, P. P., Sandakov, A. V., Grosse, G., and Grigoriev, M. N.: Short- and long-term thermo-erosion of ice-rich 
permafrost coasts in the Laptev Sea region, Biogeosciences, 10, 4297-4318, doi:10.5194/bg-10-4297-2013, 2013a (this volume). Günther, F., Overduin, P. P., Baranskaya, A., Opel, T., and Grigoriev, M. N.: Observing Muostakh Island disappear: erosion of a ground-ice-rich coast in response to summer warming and sea ice reduction on the East Siberian shelf, The Cryosphere Discuss., 7, 4101-4176, doi:10.5194/tcd-7-4101-2013, 2013b.

Hessen, D. O., Carroll, J. L., Kjeldstad, B., Korosov, A. A., Pettersson, L. H., Pozdnyakov, D., and Sørensen, K.: Input of organic carbon as determinant of nutrient fluxes, light climate and productivity in the $\mathrm{Ob}$ and Yenisey estuaries, Estuar. Coast. Shelf Sci., 88, 53-66, 2010.

Holmes, R. M., McClelland J. W., Peterson, B. J., Tank, S. E., Bulygina, E., Eglinton, T. I., Gordeev, V. V., Gurtovaya, T. Y., Raymond, P. A., Repeta, D. J., Staples, R., Striegl, R. G., Zhulidov, A. V., and Zimov, S. A.: Seasonal and Annual Fluxes of Nutrients and Organic Matter from Large Rivers to the Arctic Ocean and Surrounding Seas, Estuar. Coasts, 35, 369-382, 2012.

International Ocean Colour Coordinating Group (IOCCG): Remote Sensing of Ocean Colour in Coastal, and Other OpticallyComplex Waters, edited by: Sathyendranath, S., Reports of the International Ocean-Colour Coordinating Group, 3, IOCCG, Dartmouth, Canada, 2000.

Karlsson, E. S., Charkin, A., Dudarev, O., Semiletov, I., Vonk, J. E., Sánchez-García, L., Andersson, A., and Gustafsson, Ö.: Carbon isotopes and lipid biomarker investigation of sources, transport and degradation of terrestrial organic matter in the Buor-Khaya Bay, SE Laptev Sea, Biogeosciences, 8, 1865-1879, doi:10.5194/bg-8-1865-2011, 2011.

Kattner, G., Lobbes, J. M., Fitznar, H. P., Engbroth, R., Nöthig, E.M., and Lara, R. J.: Tracing dissolved organic substances and nutrients from the Lena River through the Laptev Sea, Arctic. Mar. Chem. 65, 25-39, 1999.

Kraberg, A. C., Druzhkova, E., Heim, B., Loeder, M. J. G., and Wiltshire, K. H.: Phytoplankton community structure in the Lena Delta (Siberia, Russia) in relation to hydrography, Biogeosciences, 10, 7263-7277, doi:10.5194/bg-10-7263-2013, 2013 (this volume).

Lantuit, H., Atkinson, D., Overduin, P.P., Grigoriev, M., Rachold, V., Grosse, G. and Hubberten, H.-W.: Coastal erosion dynamics on the permafrost-dominated Bykovsky Peninsula, north Siberia, 1951-2006, Polar Res., 30, 7341, doi:10.3402/polar.v30i0.7341, 2011.

Lantuit, H., Overduin, P. P., Couture, N., Wetterich, S., Are, F., Atkinson, D., Brown, J., Cherkashov, G., Drozdov, D., Forbes, D., Graves-Gaylord, A., Grigoriev, M., Hubberten, H. W., Jordan, J., Jorgenson, T., Ødegård, R. S., Ogorodov, S., Pollard, W., Rachold, V., Sedenko, S., Solomon, S., Steenhuisen, F., Streletskaya, I., and Vasiliev, A.: The Arctic Coastal Dynamics database. A new classification scheme and statistics on arctic permafrost coastlines, Estuar. Coasts, 35, 383-400, 2012.

Lisitsin, A. P., Shevchenko, V. P., and Burenkov, V. I.: Hydrooptics and suspended matter of Arctic seas, Atmos. Ocean. Opt., 13, 61-71, 2000.

Lobbes, J. M., Fitznar, H. P., and Kattner, G.: Biogeochemical characteristics of dissolved and particulate organic matter in Russian rivers entering the Arctic Ocean, Geochim. Cosmochim. Ac., 64, 2973-2983, 2000.
Loginova, A. N: Chromophoric dissolved organic matter in the Laptev Sea (Siberian Arctic): A comparison of in-situ observations, laboratory measurements, and remote sensing, Master Thesis MSc Applied Polar and Marine Sciences, POMOR, St. Petersburg State University (RU), and University of Hamburg (DE), 98 pp., 2011.

Matsuoka, A., Huot, Y., Shimada, K., Saitoh, S., and Babin, M.: Bio-optical characteristics of the Western Arctic Ocean: implications for ocean color algorithms, Can. J. Remote Sen., 33, 503518, 2007.

Matsuoka, A., Bricaud, A., Benner, R., Para, J., Sempéré, R., Prieur, L., Bélanger, S., and Babin, M.: Tracing the transport of colored dissolved organic matter in water masses of the Southern Beaufort Sea: relationship with hydrographic characteristics, Biogeosciences, 9, 925-940, doi:10.5194/bg-9-925-2012, 2012a.

Matsuoka, A., Huot, Y., Shimada, K., Saitoh, S., and Babin, M.: Bio-optical characteristics of the Western Arctic Ocean: Implications for ocean color algorithms, Can. J. Remote Sen., 33, 503518, 2012 b.

Matsuoka, A., Hooker, S. B., Bricaud, A., Gentili, B., and Babin, M.: Estimating absorption coefficients of colored dissolved organic matter (CDOM) using a semi-analytical algorithm for southern Beaufort Sea waters: application to deriving concentrations of dissolved organic carbon from space, Biogeosciences, 10, 917-927, doi:10.5194/bg-10-917-2013, 2013.

Mustapha, S. B., Bélanger, S., and Larouche, P.: Evaluation of ocean color algorithms in the southeastern Beaufort Sea, Canadian Arctic: New parameterization using SeaWiFS, MODIS, and MERIS spectral bands, Can. J. Remote Sen., 38, 535-556, 2012.

Örek, H., Doerffer, R., Röttgers, R., Boersma, M., and Wiltshire, K. H.: Contribution to a bio-optical model for remote sensing of Lena River water, Biogeosciences, 10, 7081-7094, doi:10.5194/bg-10-7081-2013, 2013 (this volume).

Pozdnyakov, D. V., Korosov, A. A., Pettersson, L. H., and Johannessen, O. M.: MODIS evidences the river run-off impact on the Kara Sea trophy, Int. J. Remote Sens., 26, 364-368, 2005.

Rachold, V., Grigoriev, M. N., Are, F. E., Solomon, S., Reimnits, E., Kassens, H., and Antonov, M.: Coastal erosion vs riverine sediment discharge in the Arctic Shelf seas, Int. J. Earth Sci., 89, 450-460, 2000.

Rachold, V., Eicken, H., Gordeev, V. V., Grigoriev, M. N., Hubberten, H.-W., Lisitzin, A. P., Shevchenko, V. P., and Schirrmeister, L.: Modern terrigenous organic carbon input to the Arctic Ocean, in: Organic Carbon Cycle in the Arctic Ocean: Present and Past, edited by: Stein, R. and Macdonald, R. W., 33-55, 2004.

Reimnitz, E.: Interactions of river discharge with sea ice in proximity of Arctic Deltas: a review, Polarforschung, 70, 123-134, 2000.

Schirrmeister, L., Siegert, Ch., Kunitzky, V. V., Grootes, P., and Erlenkeuser, H.: Late quaternary ice rich permafrost sequences as a palaeoenvironmental archive for the Laptev Sea region in northern Siberia, Int. J. Earth Sci., 91, 154-167, 2002.

Semiletov, I. P., Pipko, I. I., Shakhova, N. E., Dudarev, O. V., Pugach, S. P., Charkin, A. N., McRoy, C. P., Kosmach, D., and Gustafsson, O.: Carbon transport by the Lena River from its headwaters to the Arctic Ocean, with emphasis on fluvial input of terrestrial particulate organic carbon vs. carbon transport by 
coastal erosion, Biogeosciences, 8, 2407-2426, doi:10.5194/bg8-2407-2011, 2011.

Semiletov, I. P., Shakhova, N. E., Pipko, I. I., Pugach, S. P., Charkin, A. N., Dudarev, O. V., Kosmach, D. A., and Nishino, S.: Spacetime dynamics of carbon and environmental parameters related to carbon dioxide emissions in the Buor-Khaya Bay and adjacent part of the Laptev Sea, Biogeosciences, 10, 5977-5996, doi:10.5194/bg-10-5977-2013, 2013 (this volume).

Sutherland, D. A., Straneo, F., Lentz, S., and St-Laurent, P.: Observations of fresh, anticyclonic eddies in the Hudson Strait outflow, J. Mar. Syst., 88, 375-384, 2011.

Vetrov, E. A., Romankevich, E. A., and Belyaev, N. A.: Chlorophyll, primary production, fluxes, and balance of organic carbon in the Laptev Sea, Geochem. Int., 46, 1055-1063, 2008.

Vonk, J. E., Sánchez-García, L., Semiletov, I., Dudarev, O., Eglinton, T., Andersson, A., and Gustafsson, Ö.: Molecular and radiocarbon constraints on sources and degradation of terrestrial organic carbon along the Kolyma paleoriver transect, East Siberian Sea, Biogeosciences, 7, 3153-3166, doi:10.5194/bg-73153-2010, 2010.

Vonk, J. E., Sánchez-García, L., van Dongen, B. E., Alling, V., Kosmach, D., Charkin, A., Semiletov, I. P., Dudarev, O. V., Shakhova, N., Roos, P., Eglinton, T., Andersson, A., and Gustafsson, O.: Activation of old carbon by erosion of coastal and subsea permafrost in Arctic Siberia, Nature, 489, 137-140, 2012.
Wagner, D., Overduin, P. P., Grigoriev, M. N., Knoblauch, C., and Bolshiyanov, D. Y.: Russian-German cooperation System Laptev Sea: the expedition LENA 2008, Berichte zur Polar- und Meeresforschung, Bremerhaven, Alfred Wegener Institute for Polar and Marine Research, 642, 132 pp., 2012.

Wang, J. and Cota, G. F.: Remote sensing reflectance in the Beaufort and Chukchi Seas: Observations and models, Appl. Optics, 42, 2754-2765, 2003.

Wegner, C., Hölemann, J. A., Dmitrenko, I., Kirillov, S. A., Tuschling, K., Abramova, E., and Kassens, H.: Suspended particulate matter on the Laptev Sea shelf (Siberian Arctic) during ice-free conditions, Estuar. Coast. Shelf Sci., 57, 55-64, 2003.

Wegner, C., Hölemann, J. A., Dmitrenko, I., Kirillov, S. A., and Kassens, H.: Seasonal variations in sediment dynamics on the Laptev Sea shelf (Siberian Arctic), Global Planet. Change, 48, 126-140, 2005.

Wegner, C., Bauch, D., Hölemann, J. A., Janout, M. A., Heim, B., Novikin, A., Kassens, H., and Timokhov, L.: Interannual variability of surface and bottom sediment transport on the Laptev Sea shelf during summer, Biogeosciences, 10, 11171129, doi:10.5194/bg-10-1117-2013, 2013 (this volume). 